CrossMark \& click for updates

Cite this: Org. Biomol. Chem., 2015, 13,8827

\section{Reactions of $\mathrm{CF}_{3}$-enones with arenes under superelectrophilic activation: a pathway to trans-1,3-diaryl-1- $\mathrm{CF}_{3}$-indanes, new cannabinoid receptor ligands $\uparrow$}

\author{
Roman O. lakovenko, ${ }^{a}$ Anna N. Kazakova, ${ }^{a}$ Vasiliy M. Muzalevskiy, \\ Alexander Yu. Ivanov, ${ }^{c}$ Irina A. Boyarskaya, ${ }^{a}$ Andrea Chicca, ${ }^{d}$ Vanessa Petrucci, ${ }^{d}$ \\ Jürg Gertsch, ${ }^{d}$ Mikhail Krasavin, ${ }^{* a}$ Galina L. Starova, ${ }^{a}$ Andrey A. Zolotarev, ${ }^{a}$ \\ Margarita S. Avdontceva, ${ }^{a}$ Valentine G. Nenajdenko*b and Aleksander V. Vasilyev*a,e
}

\begin{abstract}
4-Aryl-1,1,1-trifluorobut-3-en-2-ones $\mathrm{ArCH}=\mathrm{CHCOCF}_{3}\left(\mathrm{CF}_{3}\right.$-enones) react with arenes in excess of Brønsted superacids $\left(\mathrm{TfOH}, \mathrm{FSO}_{3} \mathrm{H}\right)$ to give, stereoselectively, trans-1,3-diaryl-1-trifluoromethyl indanes in $35-85 \%$ yields. The reaction intermediates, the $\mathrm{O}$-protonated $\mathrm{ArCH}=\mathrm{CHC}\left(\mathrm{OH}^{+}\right) \mathrm{CF}_{3}$ and the $\mathrm{O}, \mathrm{C}$-diprotonated $\mathrm{ArHC}^{+} \mathrm{CH}_{2} \mathrm{C}\left(\mathrm{OH}^{+}\right) \mathrm{CF}_{3}$ species, have been studied by means of ${ }^{1} \mathrm{H},{ }^{13} \mathrm{C},{ }^{19} \mathrm{~F} \mathrm{NMR}$, and DFT calculations. Both types of the cations may participate in the reaction, depending on their electrophilicity and electron-donating properties of the arenes. The formation of $\mathrm{CF}_{3}$-indanes is a result of cascade reaction of protonated $\mathrm{CF}_{3}$-enones to form chemo-, regio- and stereoselectively three new $\mathrm{C}-\mathrm{C}$ bonds. The obtained trans-1,3-diaryl-1-trifluoromethyl indanes were investigated as potential ligands for cannabinoid receptors $\mathrm{CB}_{1}$ and $\mathrm{CB}_{2}$ types. The most potent compound showed sub-micromolar affinity for both receptor subtypes with a 6 -fold selectivity toward the $\mathrm{CB}_{2}$ receptor with no appreciable cytotoxicity toward SHSY5Y cells.
\end{abstract}

Received 27th May 2015

Accepted 7th July 2015

DOI: $10.1039 /$ c5ob01072a

www.rsc.org/obc

\section{Introduction}

1,1,1-Trifluorobut-3-en-2-ones ( $\mathrm{CF}_{3}$-enones) are important fluorinated building blocks having rich chemistry and are used frequently for preparation of practically valuable fluorinecontaining substances. Several approaches to synthesis of $\mathrm{CF}_{3}$ -

\footnotetext{
${ }^{a}$ Institute of Chemistry, Saint-Petersburg State University, 198504 Saint-Petersburg, Petrodvorets, Universitetsky pr., 26, Russia. E-mail:m.krasavin@spbu.ru ${ }^{b}$ Department of Chemistry, Lomonosov Moscow State University, 119899 Moscow, Russia.E-mail: nen@acylium.chem.msu.ru; Fax:+7-495-9328846; Tel: $+7-495-9392276$

${ }^{c}$ Center for Magnetic Resonance, Research Park, St. Petersburg State University, Universitetskiy pr. 26, Saint Petersburg, Petrodvorets 198504, Russia

${ }^{d}$ Institute of Biochemistry and Molecular Medicine, NCCR TransCure, University of Bern, Bühlstrasse 28, 3012 Bern, Switzerland

${ }^{e}$ Department of Chemistry, Saint Petersburg State Forest Technical University, Institutsky per., 5, Saint Petersburg, 194021, Russia. E-mail: aleksvasil@mail.ru; Fax: +7-812-6709390; Tel: +7-812-6709352

$\dagger$ Electronic supplementary information (ESI) available: Figures of ${ }^{1} \mathrm{H},{ }^{13} \mathrm{C},{ }^{19} \mathrm{~F}$ NMR spectra, X-ray data of obtained compounds, additional biological profile of compounds 2a-h,l, details of DFT calculations. CCDC 1047066, 1047331, 1047468, 1047315, 1047593 and 1048565. For ESI and crystallographic data in CIF or other electronic format see DOI: 10.1039/c5ob01072a
}

enones have been developed. ${ }^{1}$ The combination of a conjugated carbon-carbon double bond and $\mathrm{CF}_{3} \mathrm{CO}$-group present in these compounds, results in their unique electrophilic properties, leading to the reactions at either the carbonyl group ${ }^{2}$ or the double bond ${ }^{3}$ - or at both of these structural fragments. ${ }^{4} \mathrm{CF}_{3}$-enones are known to react with various $O-, S$-, $N$-, $C$-nucleophiles to give numerous polyfunctional derivatives, carbo- and heterocycles bearing a trifluoromethyl group. Many of these have been shown to possess diverse biological activities. $^{5}$

In continuation of our previous studies of reactions of $\mathrm{CF}_{3^{-}}$ alkynes in Brønsted superacids, ${ }^{6}$ and $\mathrm{CF}_{3}$-allyl alcohols under action of Lewis acids, ${ }^{7}$ we became interested in studying of the fate of $\mathrm{CF}_{3}$-enones $\mathbf{1 a}-\mathbf{h}$ (Fig. 1) under similar superelectrophilic activation. In a preliminary short communication ${ }^{8}$ we showed that 1,1,1-trifluoro-4-phenylbut-3-en-2-one 1a reacted with benzene, $o$-xylene, and veratrole in TfOH. We chose Brønsted superacids (TfOH, $\left.\mathrm{FSO}_{3} \mathrm{H}\right)^{9}$ for significant enhancement of electrophilic properties of the $\mathrm{CF}_{3}$-enones system by protonation. The main goal of this work was to investigate the protonation of butenones $\mathbf{1} \mathbf{a}-\mathbf{h}$ in superacids, the subsequent reactions of the resulting carbocations with arenes, as 


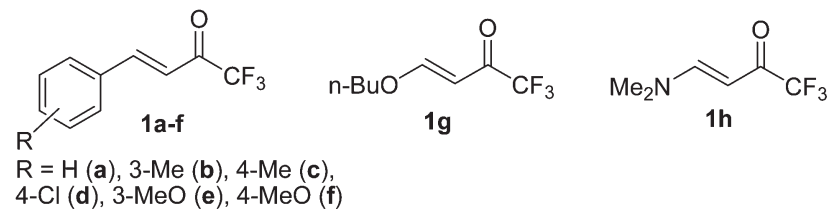

Fig. 1 Starting $\mathrm{CF}_{3}$-enones $1 \mathrm{a}-\mathrm{h}$ used in this study.

$\pi$-nucleophiles, and to test physiological activity of the resulting trifluoromethylated compounds.

\section{Results and discussion}

\section{DFT calculation of cations derived from of 4-aryl-1,1,1- trifluorobut-3-en-2-ones}

Protonation of conjugated enones ${ }^{9 a, b}$ or ynones ${ }^{9 c}$ in Brønsted superacids proceeds in two steps: first, protonation of the carbonyl oxygen occurs, followed by the second protonation of an unsaturated carbon-carbon bond. In the same way protonation of the $\mathrm{CF}_{3}$-enones system of compounds $\mathbf{1}$ gives consequently cations $\mathbf{A}$ and dications $\mathbf{B}$ (Scheme 1). The latter species are considered as superelectrophiles. ${ }^{9 b}$ Both the O-protonated (A) and the O,C-diprotonated (B) forms can be reactive electrophiles. They have two carbocationic centers (at $\mathrm{C}^{2}$ and $\mathrm{C}^{4}$ ) that may participate in further reactions.

To gain insight into the nature of formed electrophilic species we decided to study the reaction of $\mathrm{CF}_{3}$-enones with acids theoretically. In order to estimate the charge distribution in these species (as well as their electrophilicity), we performed DFT calculations for carbocations, derived from $\mathrm{CF}_{3}$-enones 1a-f (Scheme 1). Selected electronic characteristics of the O-protonated forms (A1-A6), the O,C-diprotonated forms (B1B6) are presented in the ESI (Table S9†). The global electrophilicity index can be used quite effectively to sort various electrophiles qualitatively and provide a good estimation of the activity of electrophiles. This parameter is easily calculated from the HOMO and LUMO levels. ${ }^{10}$

The data obtained show that the highest value of global electrophilicity index $\omega$ 30.3-47.5 eV belongs to dications B1-B6 that is quite predictable for doubly charged species. ${ }^{9,11}$ Apart from that, these dications have a large positive charge $(0.66-0.69 e)$ and a great contribution of an atomic orbital in the LUMO on $\mathrm{C}^{2}$ atom (18.2-34.6\%) which indicates a combined effect of charge and orbital control on the reactivity of that carbon atom. This also reveals that the O,C-diprotonated species B should be extremely reactive electrophiles (super- electrophiles ${ }^{9 b}$ ) with the $\mathrm{C}^{2}$ atom being more reactive compared to $\mathrm{C}^{4}$.

The O-monoprotonated cations A1-A6 also carry a bigger positive charge on $\mathrm{C}^{2}(0.40-0.43 e)$ atom compared to $\mathrm{C}^{4}$ (0.02-0.07e). However, the latter has a slightly bigger contribution of atomic orbital to the LUMO (26.5-29.7\%). It may determine the predominance of orbital control in reactivity of $\mathrm{C}^{4}$ atom for cations A1-A6.

Thus, the DFT calculations predict that in principle both cationic species $\mathbf{A}$ and $\mathbf{B}$ derived from $\mathbf{1}$ (Scheme 1) may act as electrophiles. The atom $\mathbf{C}^{2}$ is the reactive center in dications $\mathbf{B}$. Cations A may possess two centers (atoms $\mathrm{C}^{2}$ and $\mathrm{C}^{4}$ ) for the reaction with nucleophiles.

\section{NMR study of $\mathrm{CF}_{3}$-enone protonation in superacids}

In order to confirm DFT predictions we investigated protonation of $\mathrm{CF}_{3}$-enones in $\mathrm{TfOH}$ and $\mathrm{FSO}_{3} \mathrm{H}$ at various temperatures by means of $\mathrm{NMR}$. It was found that $\mathrm{CF}_{3}$-enones $\mathbf{1 a , c , d , f}$, h afforded stable O-protonated species A1, A3, A4, A6, A7, respectively, at temperatures below $-20{ }^{\circ} \mathrm{C}$. ${ }^{1} \mathrm{H},{ }^{13} \mathrm{C}$, and ${ }^{19} \mathrm{~F}$ NMR data of these carbocations and the corresponding starting materials are given in the ESI (Table S1†). ${ }^{13} \mathrm{C}$ NMR signals of ions A1, A3, A4, A6, A7 were carefully assigned using HSQC $(\mathrm{C}-\mathrm{H})$ experiments. The signal of proton bound to the carbonyl oxygen was not detected, due to a quick proton exchange with superacidic media. ${ }^{9}$ At higher temperatures (above $-20{ }^{\circ} \mathrm{C}$ ), subsequent protonation of the carbon-carbon double bond can take place and the corresponding superelectrophilic dications B are formed. Unfortunately, we failed to detect these dications in the NMR spectra, due to their extreme instability and high reactivity, which is peculiar to superelectrophiles. ${ }^{9 b}$ At higher temperatures $\left(-20\right.$ to $\left.0^{\circ} \mathrm{C}\right)$, the spectral data pointed out the formation of complex mixtures of oligomeric reaction products (vide infra). In contrast to other $\mathrm{CF}_{3}$-enones, compound $\mathbf{1 h}$ gave an extremely stable (even at $60^{\circ} \mathrm{C}$ ) and unreactive cation A7.

Comparison of the spectra of aryl substituted cations A1, A3, A4, A6 and their neutral precursors 1a,c,d,f revealed that the signals corresponding to proton $\mathrm{H}^{4}$ and carbon $\mathrm{C}^{4}$ under-

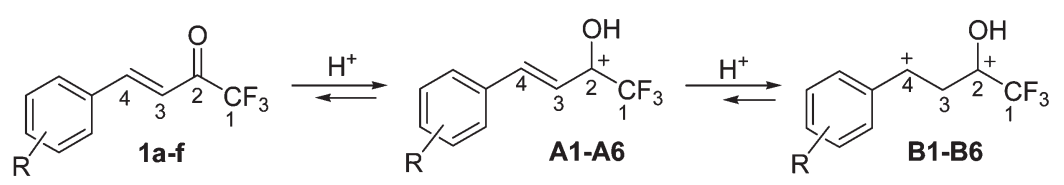

Scheme 1 Protonation of $\mathrm{CF}_{3}$-enones. 
went substantial downfield shifts: $\Delta \delta_{\mathrm{H}} \sim 1.1-1.7 \mathrm{ppm}$ in ${ }^{1} \mathrm{H}$ NMR and $\Delta \delta_{\mathrm{C}} \sim 20-30 \mathrm{ppm}$ in ${ }^{13} \mathrm{C}$ NMR (Table S1 $\uparrow$ and Fig. 2). Such spectral changes indicated a partial positive charge delocalization on carbon $\mathrm{C}^{4}$ and contribution of the corresponding resonance structure $\mathbf{A}^{\prime}$ (Table $\mathrm{S} 1 \dagger$ ). On the other hand, the carbonyl carbon $\mathrm{C}^{2}$ (in ${ }^{13} \mathrm{C} \mathrm{NMR}$ ) underwent only slight upfield shifts upon protonation which additionally argues in favor of form $\mathbf{A}^{\prime}$. Apart from that, in ${ }^{1} \mathrm{H}$ and ${ }^{13} \mathrm{C}$ NMR spectra of species A1, A3, A4, A6 the signals of the ortho- and meta-protons and carbons of the aromatic ring are non-equivalent. This indicates a contribution of another resonance structure $\mathbf{A}^{\prime \prime}$ (Table S1 $\dagger$ ), in which restricted rotation around the $\mathrm{C}^{4}-\mathrm{C}_{\mathrm{i}}$ bond is possible. This resonance form has a significant contribution in the case of para-methoxy substituted cation $\mathbf{A}^{\prime \prime} \mathbf{6}$, in which the signal of the $\mathrm{C}_{\mathrm{p}}$ atom is shifted to $180.8 \mathrm{ppm}$, compared to $150.1 \mathrm{ppm}$ in the non-protonated starting material 1f (see Fig. 2). Dimethylamino substituted cation is also characterized by resonance $\mathbf{A}^{\prime}$ 7 (Table $\mathrm{S} 1 \dagger$ ).

Thus, NMR data indicates a significant delocalization of positive charge from $\mathrm{C}^{2}$ to $\mathrm{C}^{4}$ in the O-protonated species $\mathbf{A}$, despite the fact that the DFT calculations did not predict a substantial charge re-distribution (see Table S9†). These data suggest that carbocations A are likely to react with nucleophiles primarily at $\mathrm{C}^{4}$.

\section{Reaction of $\mathrm{CF}_{3}$-enones with arenes in superacids}

Having gathered the NMR data relevant to the protonation of $\mathrm{CF}_{3}$-enones 1, we proceeded to study the behavior of compounds $\mathbf{1}$ in superacids. In $\mathrm{TfOH}$ at $20^{\circ} \mathrm{C}, \mathrm{CF}_{3}$-enones $\mathbf{1 a}-\mathbf{c}, \mathbf{e}$ are converted quantitatively into mixtures of oligomers consisting of at least 6 units of the starting butanone (according to MALDI mass spectrometry data, see ESI $\dagger$ ). Indeed, the observed oligomerization is a likely fate for dications $\mathbf{B}$ formed in the absence of intercepting nucleophiles in the reaction medium.

We were then curious to see if addition of carbocation aromatic traps, such as benzene or other arenes, would change the course of the transformation of butenones 1 in superacids (Table 1 and Schemes 2 and 3). Under the conditions that give rise to species $\mathbf{A 1}\left(-40\right.$ to $-20{ }^{\circ} \mathrm{C}, \mathrm{FSO}_{3} \mathrm{H}$ or $\left.\mathrm{TfOH}\right), \mathrm{CF}_{3}$-enones 1a demonstrated no appreciable conversion in the presence of an excess amount of benzene (entries 5 and 7, Table 1). Also, in $\mathrm{TfOH}$ cations $\mathbf{A} 3$ (at $-20^{\circ} \mathrm{C}$ ) and $\mathbf{A} 7$ (even on heating up to $60{ }^{\circ} \mathrm{C}$ ), derived from compounds $1 \mathrm{c}$ and $\mathbf{1 h}$, correspondingly, did not react with benzene. Thus, these particular O-protonated forms (A1, A3, A7) are not reactive toward benzene under these conditions.

The reaction of compound $\mathbf{1 a}$ with benzene in neat $\mathrm{TfOH}$ at $20{ }^{\circ} \mathrm{C}$ (i.e. when intermediate dication $\mathbf{B} 1$ is likely to be formed) afforded indane $\mathbf{2 a}$ in $84 \%$ yield (entry 1 , Table 1 ). Use of less amount of $\mathrm{TfOH}$ gave unsatisfactory results (entries 2 and 3). Compared to TfOH, other Brønsted (entries 4 and 6) or Lewis (entries 8-11) acids were not as efficient in promoting the same transformation.

The obtained indane $\mathbf{2 a}$ is the result of a very deep transformation of 1a, in which both carbons $\mathrm{C}^{2}$ and $\mathrm{C}^{4}$ participate in the reaction. It should be pointed out that two molecules of benzene participated in the reaction and three new carboncarbon bonds are formed. Also the stereochemistry of the reaction is quite significant. According to the NMR data, only one diastereomer is formed having trans-arranged phenyl groups in a cyclopentane ring of the indane system.

For comparison, other conjugated enones, such as alkene carbaldehydes or ketones, ${ }^{12 a-c}$ alkene carboxylic acids ${ }^{12 d-j}$ and their chloro anhydrides ${ }^{12 k, l}$ or amides, ${ }^{12 m-q}$ undergo hydroarylation of the carbon-carbon double bond in reactions with arenes under activation with Brønsted superacids, strong Lewis acids or acidic zeolites. But in the reactions of these enones the carbonyl group remains unaffected. Introduction of an electron-withdrawing $\mathrm{CF}_{3}$-substituent into the enone system of 1a leads to additional electrophilic activation of carbonyl carbon $\mathrm{C}^{2}$, which takes part in the reaction with benzene (Table 1). It should be also noted that for some enones ${ }^{12 f, q-t}$ the formation of stable O,C-diprotonated species (like dications B, Scheme 1) in superacids was detected by means of NMR.

The structures of indanes 2 (vide infra) were unambiguously determined by means of ${ }^{1} \mathrm{H},{ }^{13} \mathrm{C},{ }^{19} \mathrm{~F}$ NMR spectroscopy, highresolution mass-spectrometry, and X-ray (Fig. 4). The relative stereochemistry of products 2 was established by NOESY experiments (Fig. 3). It should be noted that this reaction is highly stereoselective, leading to indane with exclusively transorientation of aryl groups. In addition we studied the molecular structure of $\mathbf{2 a}$ by X-ray crystallography. The structure was totally in agreement with NMR data to confirm trans-orientation of phenyl rings (see Fig. 4a).

An indane (indene) fragment is a very important structural unit of a large number of bioactive and pharmaceutically interesting molecules as well as modern catalysts for polymerization. 2-Trifluormethylated indanes are an important type of indane derivatives, which have been used in biological study as well as precursors for indene synthesis. However, so far the existing approaches to trifluoromethylated indanes have some restrictions. ${ }^{12 i, 13}$ The synthesis proposed in this investigation is quite straightforward to construct highly desirable $\mathrm{CF}_{3}$-indane derivatives from arene and the corresponding $\mathrm{CF}_{3}$-enones in one-pot sequence.

Having found the reaction conditions leading to the formation of indane $2 \mathrm{a}\left(\mathrm{TfOH}, 20^{\circ} \mathrm{C}, 1 \mathrm{~h}\right)$ we decided to study the scope of the reaction and possible mechanism of the transformation. For this aim a set of arenes and $\mathrm{CF}_{3}$-enones $\mathbf{1 a}-\mathbf{h}$ were studied under conditions of superelectrophilic activation (see the Experimental section). It was found that enone 1a reacts in a similar way with other arenes, for example, $o$-xylene and 1,2-dimethoxybenzene (veratrole) to form trifluoromethylated indanes $\mathbf{2 b}, \mathbf{2 c}$ in high yields (Scheme 2). Similar adducts $\mathbf{2 e - h}$ were isolated in good to high yields by the reaction of enone 1d with benzene, $o$ - and $m$-xylenes and veratrole (electron rich aromatics). Compound $\mathbf{2 d}$ was obtained from a reaction of 1c with benzene. It should be pointed out that in all cases we observed the highly stereoselective formation of trifluoromethylated indanes. According to the reaction mech- 


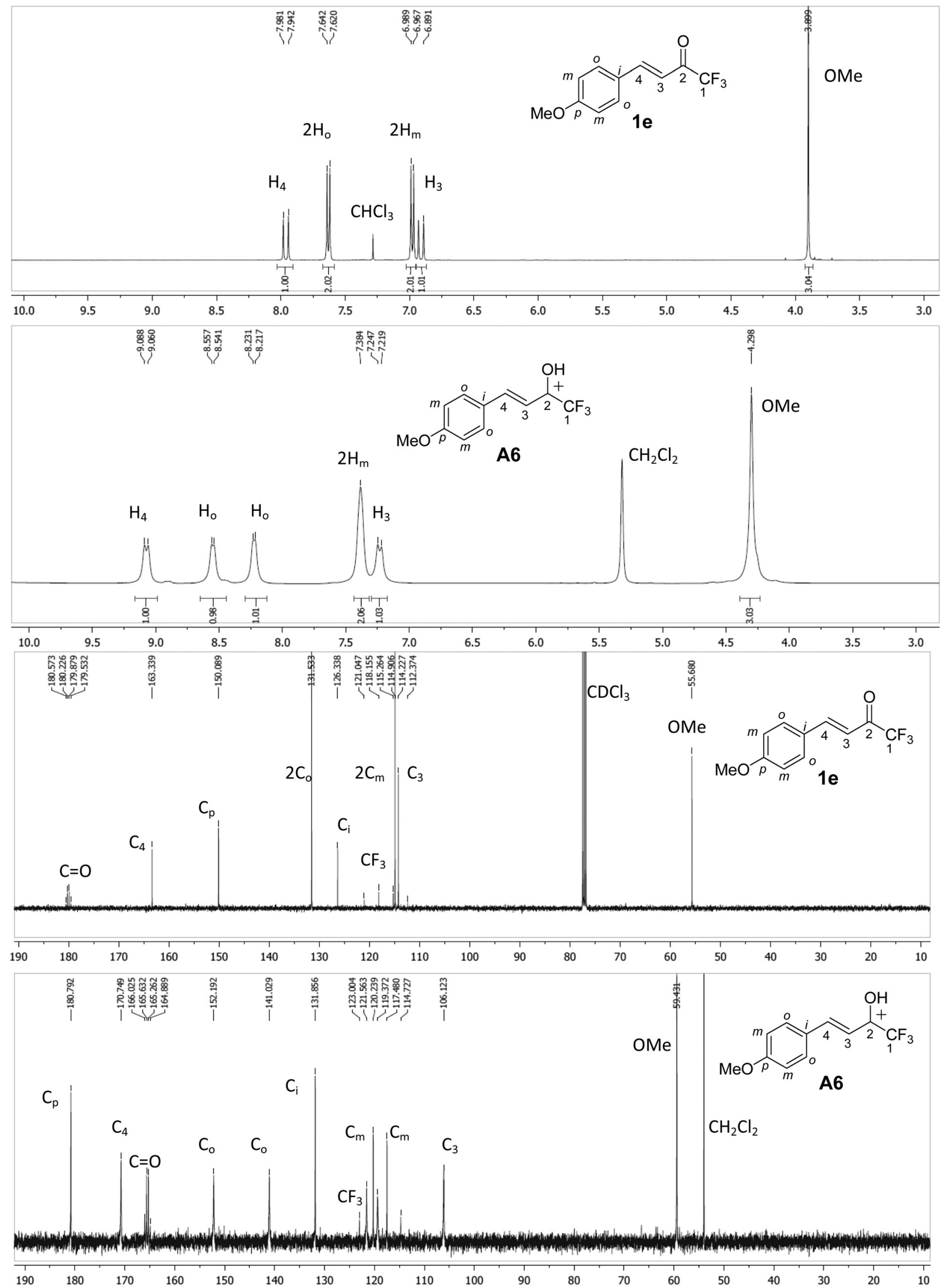

Fig. 2 Comparison of ${ }^{1} \mathrm{H}$ and ${ }^{13} \mathrm{C}$ NMR spectra of $1 \mathrm{f}\left(\mathrm{CDCl}_{3}, 20^{\circ} \mathrm{C}\right)$ and cation $\mathrm{A} 6\left(\mathrm{FSO}_{3} \mathrm{H},-60{ }^{\circ} \mathrm{C}\right)$. 
Table 1 Reactions of $\mathrm{CF}_{3}$-enone $1 \mathrm{a}$ with benzene (12 equiv.) under the action of various acids

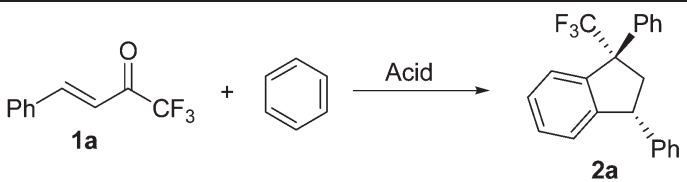

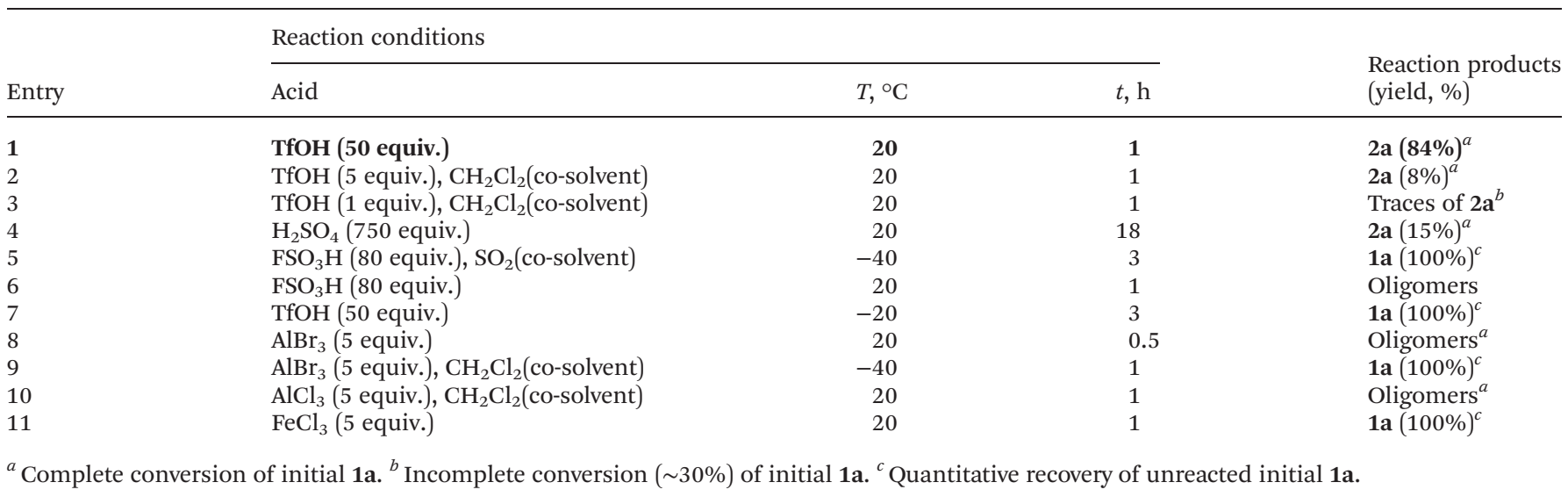

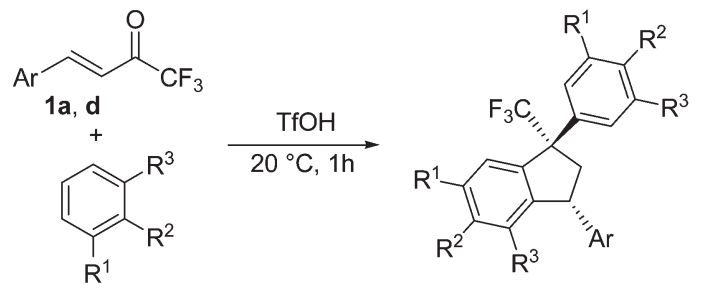

$\mathrm{Ar}=\mathrm{Ph}, \mathrm{R}^{1}=\mathrm{R}^{2}=\mathrm{Me}, \mathrm{R}^{3}=\mathrm{H}, \mathbf{2 b}, \mathbf{7 7} \%$

$\mathrm{Ar}=\mathrm{Ph}, \mathrm{R}^{1}=\mathrm{R}^{2}=\mathrm{MeO}, \mathrm{R}^{3}=\mathrm{H}, 2 \mathrm{c}, 75 \%$

$\mathrm{Ar}=4-\mathrm{ClC}_{6} \mathrm{H}_{4}, \mathrm{R}^{1}=\mathrm{R}^{2}=\mathrm{R}^{3}=\mathrm{H}, 2 \mathbf{e}, 80 \%$

$\mathrm{Ar}=4-\mathrm{ClC}_{6} \mathrm{H}_{4} \mathrm{R}^{1}=\mathrm{R}^{2}=\mathrm{Me}, \mathrm{R}^{3}=\mathrm{H}, \mathbf{2 f}, 57 \%$

$\mathrm{Ar}=4-\mathrm{ClC}_{6} \mathrm{H}_{4}, \mathrm{R}^{1}=\mathrm{R}^{3}=\mathrm{Me}, \mathrm{R}^{2}=\mathrm{H}, \mathbf{2 g}, 54 \%$

$\mathrm{Ar}=4-\mathrm{CIC}_{6} \mathrm{H}_{4}, \mathrm{R}^{1}=\mathrm{R}^{2}=\mathrm{MeO}, \mathrm{R}^{3}=\mathrm{H}, \mathbf{2 h}, 73 \%$

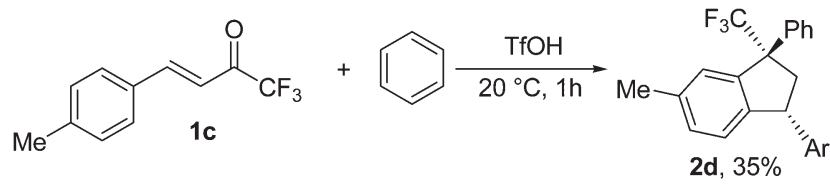

Scheme 2 Reaction of $\mathrm{CF}_{3}$-enones $1 \mathrm{a}, \mathrm{c}, \mathrm{d}$ with electron rich aromatics.

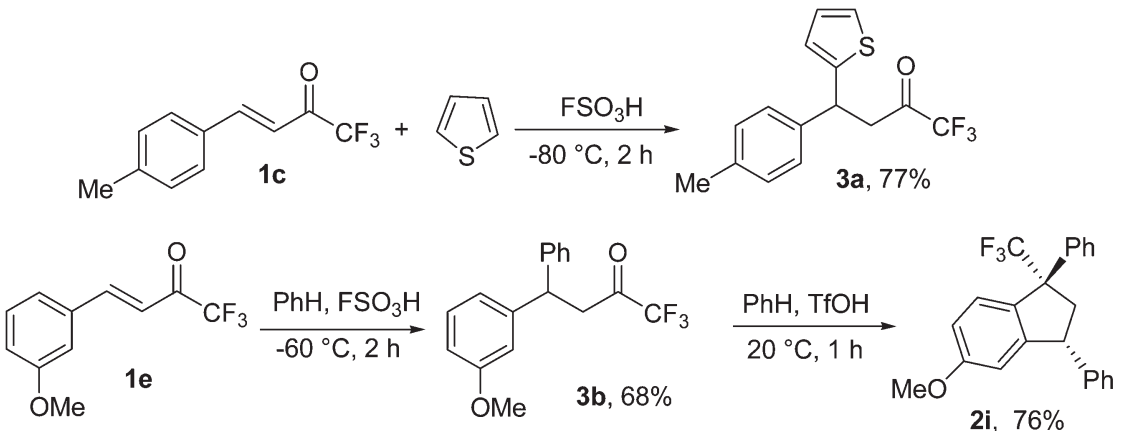

Scheme 3 Stepwise addition of arenes to $\mathrm{CF}_{3}$-enones 1 

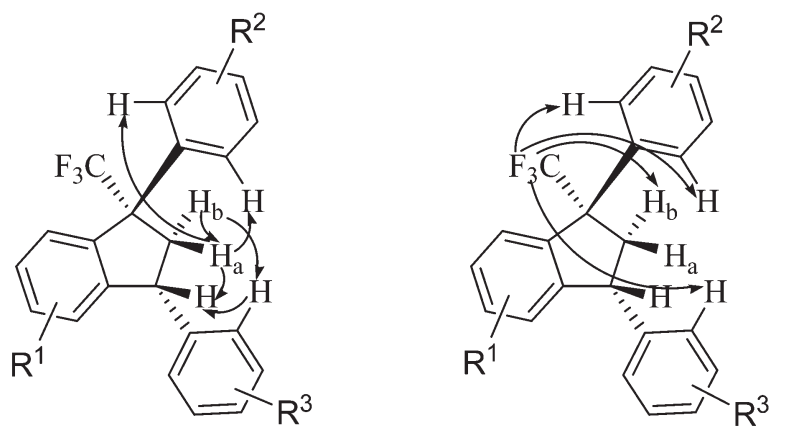

Fig. $3{ }^{1} \mathrm{H},{ }^{1} \mathrm{H}$ NOESY (left) and ${ }^{1} \mathrm{H},{ }^{19} \mathrm{~F}$ HOESY (right) correlations, proving stereochemical configuration of indanes 2 .

anism (vide infra) the cyclization in the case of the reaction of enones with aromatics having different substituents could result in formation of mixture of cyclization products, however as a rule the reaction proceeds highly chemoselectively and the cyclization proceeds into the most nucleophilic aromatic ring. The structures of some indanes were confirmed using X-ray data (Fig. 4).

We found that the reaction is extremely sensitive to steric demands. To our surprise the reaction of enone $1 \mathbf{d}$ with $m$-xylene resulted not in the expected product of the attack to 4-position of $m$-xylene but the formation of 2-trifluoromethylated indane $2 \mathrm{~g}$, bearing a 3,5-dimethylphenyl group at $\mathrm{C}-2$ atom. According to X-ray data (Fig. 4d) this aromatic ring is attached to the indane core exactly. We believe that this regiochemistry can be explained by high steric bulkiness of the $\mathrm{CF}_{3}$ group which has a quite significant conformation energy of $2.1 \mathrm{kcal} \mathrm{mol}{ }^{-1} \cdot{ }^{14}$ As a result in the case of the reaction with $m$-xylene thermodynamically controlled electrophilic substitution is observed.

For molecules of all studied compounds 2a,b,e,g,h (Fig. 4) a pentagonal ring of the indane system is a regular envelope with atoms $\mathrm{C}^{1}, \mathrm{C}^{3}, \mathrm{C}^{4}, \mathrm{C}^{5}$ as the base and $\mathrm{C}^{1}, \mathrm{C}^{2}, \mathrm{C}^{3}$ as the lid. The angle between base and lid planes of the envelope change from $35.66(9)^{\circ}$ for $2 \mathrm{~g}$ to $32.0(1)^{\circ}$ for $2 \mathbf{c}$. The $\mathrm{CF}_{3}$-group deviates to the envelope lid (the angle of deviation changes weakly from $110.6(1)^{\circ}$ for $2 \mathbf{h}$ to $111.9(1)^{\circ}$ for $\mathbf{2 g}$ ). The benzene ring plane of the indane system has no deviation from the envelope base plate practically (limits are from $0.3(1)^{\circ}$ for $2 \mathbf{b}$ to $3.1(1)^{\circ}$ for $2 \mathrm{~g}$ ). Planes of aryl substituents are bended to the envelope base with angle $72.33(6)^{\circ}$ for $2 \mathrm{~g}-77.1(1)^{\circ}$ for $2 \mathrm{a}$ and $66.74(9)^{\circ}$ for $\mathbf{2 h}-76.90(6)^{\circ}$ for $\mathbf{2 b}$ of the indane system atoms $\mathrm{C}^{1}$ and $\mathrm{C}^{3}$, correspondingly. The analysis of molecule conformations of these five studied compounds (Fig. 4), having no substituents at atom $\mathrm{C}^{2}$ of the indane system, and the published earlier

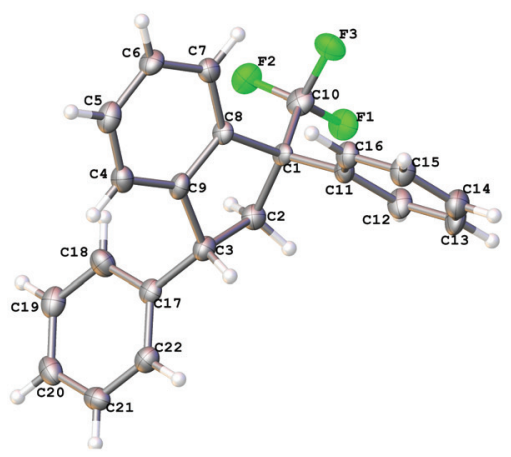

a

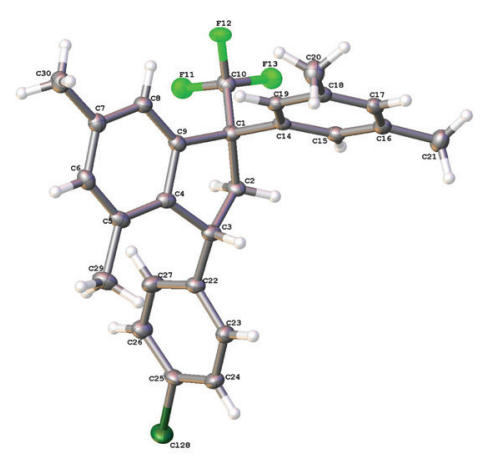

d

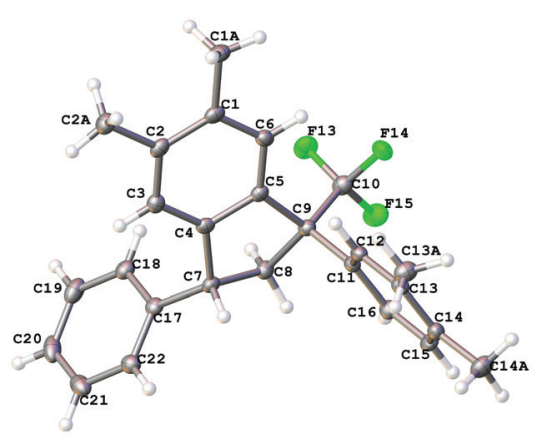

b

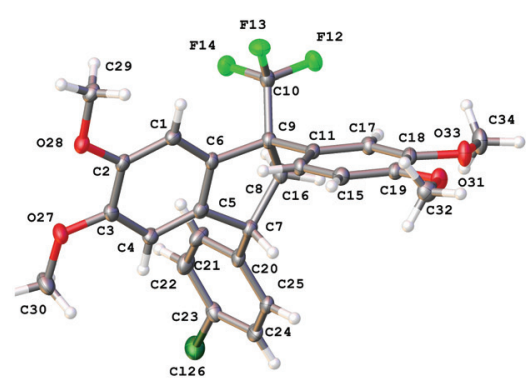

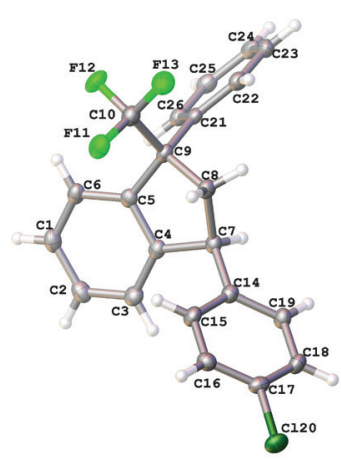

c

\section{e}

Fig. 4 X-ray crystal structures of compounds $2 \mathrm{a}(\mathrm{a}), 2 \mathrm{~b}(\mathrm{~b}), 2 \mathrm{e}(\mathrm{c}), 2 \mathrm{~g}$ (d), $2 \mathrm{~h}$ (e) (ellipsoid contour of probability levels are $50 \%$ ). 


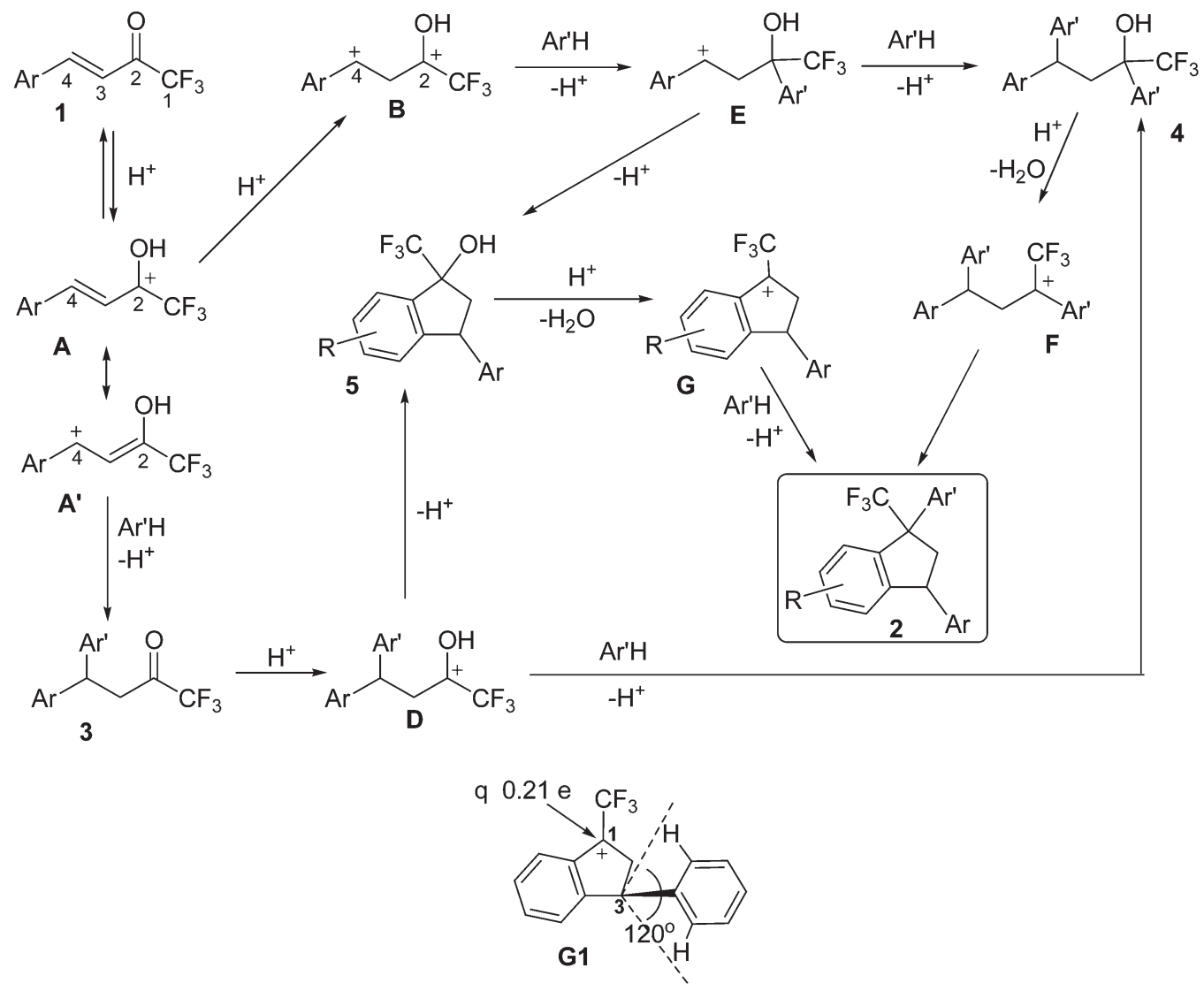

Scheme 4 Possible mechanism of the transformation of $\mathrm{CF}_{3}$-enones 1 into indanes 2. DFT calculations of parameters of cation G1.

compounds show that variation of substituents at atoms $\mathrm{C}^{1}$ and $\mathrm{C}^{3}$ of the indane system changes very slightly the configuration of the indane core. ${ }^{13 f, 15}$

The formation of indanes 2 indicates that both electrophilic carbons $\mathrm{C}^{2}$ and $\mathrm{C}^{4}$ of cationic intermediates $\mathbf{A}$ or $\mathbf{B}$ participated in the reaction. Interestingly, electron-rich substrates, such as $o$-xylene or thiophene, reacted with $\mathrm{CF}_{3}$-enones 1a,c in $\mathrm{FSO}_{3} \mathrm{H}$ at -80 to $-60{ }^{\circ} \mathrm{C}$, i.e. under the conditions that favor the formation of O-protonated species A1, A3 (see Table S1 $\dagger$ ). We also obtained very interesting results under these conditions to give clues to the reaction mechanism. We were able to stop reaction at the first step and isolate in very good yields the products of hydroarylation of enones 2 , which are most probably the intermediates of this reaction formed on the first step of the reaction sequence. For example, the reaction of enone $1 \mathrm{c}$ with thiophene $\left(-80^{\circ} \mathrm{C}, \mathrm{FSO}_{3} \mathrm{H}\right)$ gave only the corresponding 3,3-diarylbutanone $\mathbf{3 a}$ in $77 \%$ yield (Scheme 3 ). The reaction of $\mathrm{CF}_{3}$-enone $1 \mathrm{e}$ with benzene in $\mathrm{FSO}_{3} \mathrm{H}$ at $-60{ }^{\circ} \mathrm{C}$ gave $\mathrm{CF}_{3}$-enone $3 \mathbf{b}$ in $68 \%$ yield (Scheme 3 ). In addition we confirmed that these types of compounds can be transformed into indanes. For instance, the reaction of $\mathbf{3} \mathbf{b}$ with benzene in $\mathrm{TfOH}$ at $20{ }^{\circ} \mathrm{C}$ gave the expected indane $2 \mathbf{i}$ in $76 \%$ yield (Scheme 3).

All these data clearly demonstrate that cations $\mathbf{A}$ are generally able to react at $\mathrm{C}^{4}$ with electron rich arenes and hetero- arenes. However, the highly electrophilic versions of these cations, like A5 (based on its $\omega$ values presented in Table S9†) generated from 1e, can also react with less nucleophilic arenes like benzene, also at $\mathrm{C}^{4}$ (Scheme 3). Finally, we believe that the reactions of $\mathrm{CF}_{3}$-enones $\mathbf{1 a}-\mathbf{d}, \mathbf{f}$ with benzene in $\mathrm{TfOH}$ at $20{ }^{\circ} \mathrm{C}$ are likely to proceed via the intermediate formation of dications B.

\section{Discussion on reaction mechanism}

Analyzing DFT calculations obtained for cations A, B (Table S9 $\dagger$ ), NMR (Table S1 $\dagger$ ) and experimental data (Table 1 and Schemes 2 and 3), we conclude that species $\mathbf{A}$ and $\mathbf{B}$ initially can react with nucleophiles at $\mathrm{C}^{4}$ and $\mathrm{C}^{2}$ respectively. Based on this conclusion, one can propose the following reaction pathways for the transformation of $\mathrm{CF}_{3}$-enones $\mathbf{1}$ into indanes 2 (Scheme 4). The reaction of arenes with cation $\mathbf{A}$ at carbon $\mathrm{C}^{4}$ can give compound $\mathbf{3}$, and subsequent protonation leads to formation of cation $\mathbf{D}$. The latter one can react further in two ways: intermolecularly, with the arene, to give rise to compound 4, or intramolecularly - to afford after cyclization indanol 5. Compounds $\mathbf{4}$ and $\mathbf{5}$ may also be obtained via the reaction of dication $\mathbf{B}$ with an arene at $\mathrm{C}^{2}$ to result in the formation of cation $\mathbf{E}$. Subsequent transformations of $\mathbf{4}$ and $\mathbf{5}$ can proceed with an intermediate formation of cations $\mathbf{F}$ and $\mathbf{G}$, respectively, culminating in the formation of indanes 2 . 

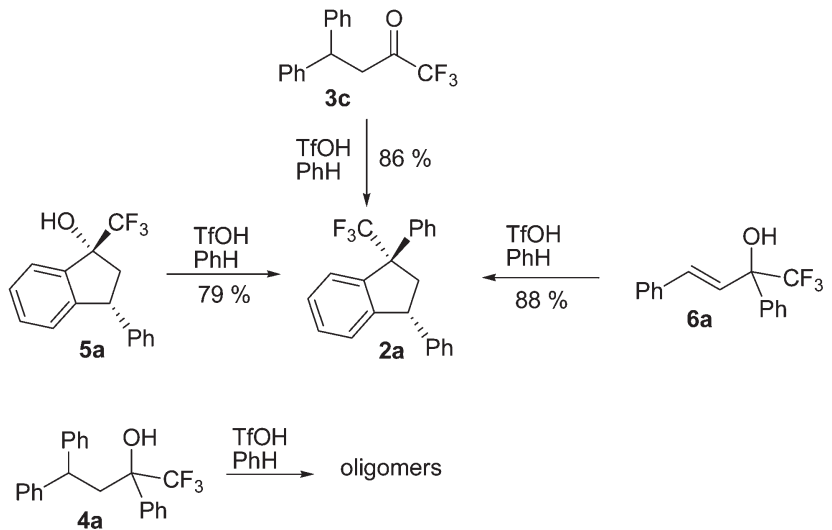

Scheme 5 Transformations of compounds 3c, 5a, 4a, 6a with benzene in $\mathrm{TfOH}\left(20^{\circ} \mathrm{C}, 10 \mathrm{~min}\right)$.

In order to validate the abovementioned mechanistic interpretation, we synthesized compounds 3c, 5a, 4a, 6a (see their synthesis and X-ray structure of 13 in the ESI $\dagger$ ) all of which can be implicated as intermediates on route from 1 to 2 , and exposed them in $\mathrm{TfOH}$ with an excess of benzene (Scheme 5).

The reaction of diarylbutanone $\mathbf{3 c}$ with benzene under activation with triflic acid gave indane 2a in high yield. Analogously compound $\mathbf{3 b}$ afforded $\mathbf{2 l}$ (Scheme 3). Indanol 5a can also be transformed into $2 \mathrm{a}$ under the same conditions in $79 \%$ yield. Interestingly, while alkenol $\mathbf{6 a}$ had not initially been thought to be an intermediate in the proposed mechanistic rationale (Scheme 5), we also found it to give rise to $2 \mathbf{a}$ under the reaction conditions. However, isolation of diarylbutanones 3 under lower temperature indicates that this route to the final indanes is most probable, therefore participation of 6a can be discussed as a minor reaction route. In contrast, compound $\mathbf{4 a}$ was not transformed into indane 2a (Scheme 5), making us question its involvement in the above transformations.

Thus, there are two most likely reaction pathways: (1) through cation A to structures 3, D, 5, G, and 2; or (2) through cation $\mathbf{B}$ to structures $\mathbf{E}, \mathbf{5}, \mathbf{G}$, and $\mathbf{2}$. Cation $\mathbf{G}$ is one of the key intermediates of this reaction for both pathways. The addition of an aromatic molecule to the latter leads to trans-orientation of the bulky aromatic groups, probably due to steric reasons. DFT calculation of charge distribution in cation G1 and its geometry was done (see ESI $\dagger$ ). Large positive charge $(0.21 e)$ is localized on the reactive center $\mathrm{C}^{1}$ of the indane system (Scheme 4). Geometry of this species exhibits that the cone angle with the apex at atom $\mathrm{C}^{3}$ and ortho-protons of the phenyl ring is around $120^{\circ}$ (Scheme 4), revealing rather great steric restriction for attack of an arene molecule from this side of the indane plane. Apart from that, DFT calculations have shown that difference between the Gibbs energies of cis- and trans-isomers $2 \mathrm{a}$ is $1.1 \mathrm{kcal} \mathrm{mol}^{-1}$ in favor of the trans-isomer (see ESI $\dagger$ ).

Concerning mechanisms of superelectrophilic activation of conjugated enones, in 1990s Shudo and Ohwada ${ }^{12 a, b}$ postulated formation of reactive O,O-diprotonated at carbonyl oxygen species, which may lie on reaction pathways. One may not exclude the participation of the dications in reactions, but up to the moment these species have not been yet detected by NMR or other physical methods, contrary to reliably characterized O,C-diprotonated forms of enones. ${ }^{12 f, q-t}$

Additionally we observed two unusual reactions for $\mathrm{CF}_{3}$ enones 1f and 1g. In both cases, the formation of indane $\mathbf{2 a}$ was observed (Scheme 6). That means that an exchange of $p$-anisyl (for 1f) or $n$-BuO (for 1g) substituents takes place under superacidic reaction conditions. In the case of butoxy enone the transformation to 1a takes place and some examples of similar transformations $\mathrm{CF}_{3}$-enones are known in the literature. ${ }^{1 h, 16}$ However, it is more difficult to explain the results of the reaction with 1f. It is clear that electrophilic substitution with removal of anisole (good electrofuge) takes place. However, it is most probable that the enone 1a is not the major intermediate of the reaction because a mixture of cisand trans-indanes $\mathbf{2 a}$ is formed. In addition, substitution of anisole may take place from the initially formed indane structure.

Summarizing the discussion of the reaction mechanism, one may conclude that both O-protonated A and O,C-diprotonated $\mathbf{B}$ species take part in the reactions of $\mathbf{1}$ with arenes in superacids. The electrophilicity of these cations as well as its match to the electron-donating properties of the arenes
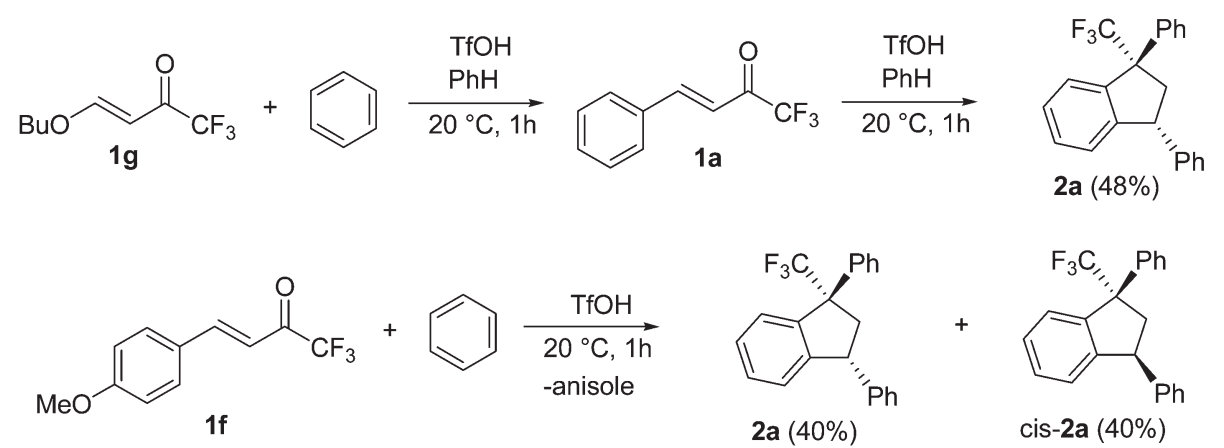

Scheme 6 Reactions of compounds $\mathbf{1 f}, \mathbf{1 g}$ with benzene in TfOH. 
Table 2 clog $P$ values calculated (using ACD/Labs 6.00 software) for trans-1,3-diaryl-1-trifluoromethyl indanes synthesized in this work

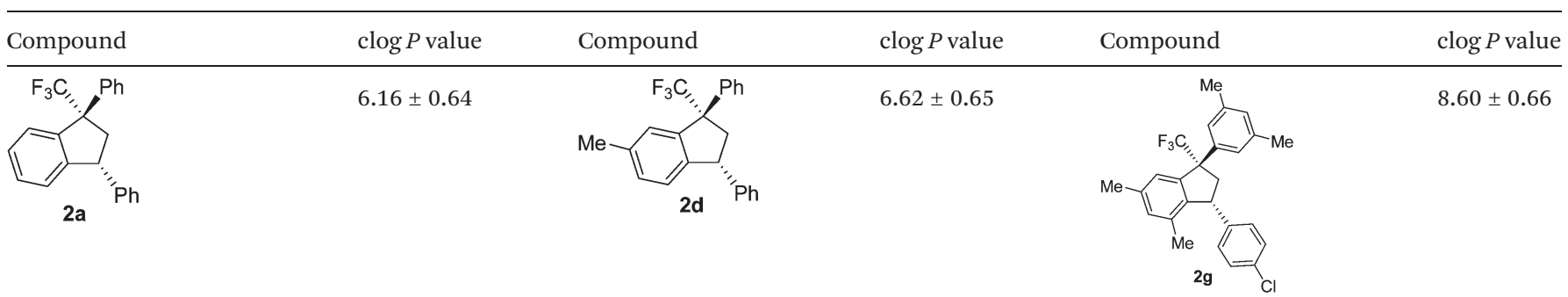

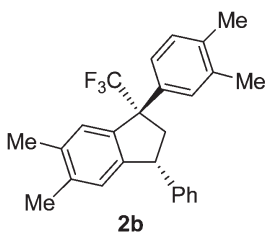

$8.00 \pm 0.65$

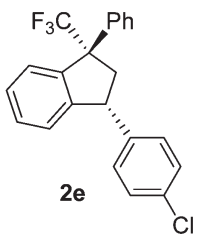

$6.76 \pm 0.65$

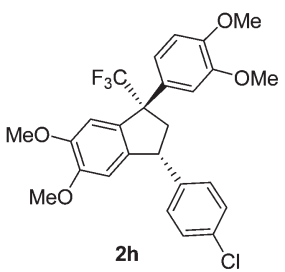

$8.60+0.66$
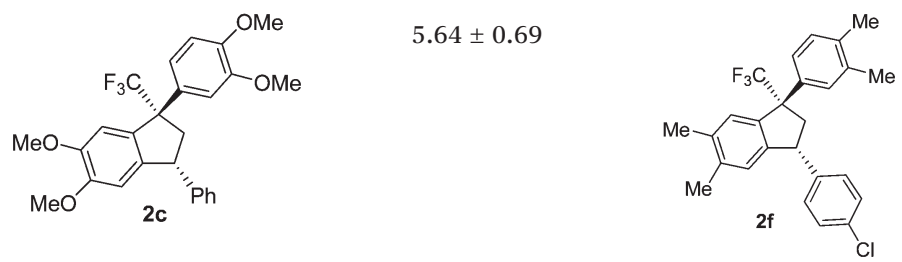

$5.64 \pm 0.69$

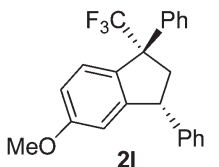

$6.08 \pm 0.65$ defines the outcome of the reaction. Strong electrophilic cations A react even with poor nucleophilic arenes, such as benzene. On the other hand, cations A, having moderate electrophilicity, react primarily with electron-rich arenes (xylenes, veratrole, etc.). Dications $\mathbf{B}$ are highly reactive superelectrophiles, reacting with all aromatic substrates. In some cases this reaction may proceed through mixed mechanisms with participation of both cations $\mathbf{A}$ and $\mathbf{B}$.

\section{Effects of 1,3-diaryl-1-trifluoromethyl indanes on the endocannabinoid system}

The new trans-1,3-diaryl-1-trifluoromethyl indanes $\mathbf{2 a - h}, \mathbf{l}$, which we succeeded in obtaining as individual substances in this work, are distinctly lipophilic compounds (Table 2). With the aim of investigating the biological effects of this newly conceived scaffold, we assessed the binding properties of these compounds on cannabinoid receptors, which are the target of endogenous molecules called endocannabinoids that are also distinctly lipophilic.

The highly lipophilic $N$-arachidonoylethanolamine (AEA or anandamide) and 2-arachidonoylglycerol (2-AG) are the most abundant and well-studied endocannabinoids and exert their biological activity primarily by binding to type- $1\left(\mathrm{CB}_{1}\right)$ and type-2 $\left(\mathrm{CB}_{2}\right)$ cannabinoid receptors. ${ }^{17}$ Most of the nonendogenous ligands for $\mathrm{CB}_{1}$ and $\mathrm{CB}_{2}$ are also characterized by high lipophilicity, for example the phytocannabinoid $\Delta^{9}$-tetrahydrocannabinol $\left(\Delta^{9}\right.$-THC) and the synthetic non-classical cannabinoids - SR141716A, ${ }^{18} \mathrm{JWH}^{8} 15^{19}$ and $\mathrm{LY}^{19} 20135^{20}$ (Fig. 5). It is the lipophilic nature of trans-1,3-diaryl-1-trifluoro- methyl indanes and the obvious similarity with the above synthetic cannabinoids (in terms of the arrangement of the aromatic periphery - vide infra) that further supported our hypothesis of investigating the potential binding affinity of these molecules toward cannabinoid receptors.

Eight compounds $\mathbf{2 a}, \mathbf{2 c}, \mathbf{2 d - h}, \mathbf{l}$ were screened for their ability to displace $\left[{ }^{3} \mathrm{H}\right] \mathrm{CP} 55,940$ (the radiolabelled analogue of CP55,940, a potent, non-selective classical $\mathrm{CB}_{1}$ and $\mathrm{CB}_{2}$ ligand ${ }^{21}$ ) from $\mathrm{CB}_{1}$ and $\mathrm{CB}_{2}$ receptors. To our delight, three compounds (2c, $2 \mathbf{e}$ and $\mathbf{2 h}$ ) showed a significant (higher than $50 \%$ ) displacement of $\left[{ }^{3} \mathrm{H}\right] \mathrm{CP} 55,940$ at the screening concentration of $1 \mu \mathrm{M}$. In addition, none of these compounds showed significant cytotoxicity at the concentration of $10 \mu \mathrm{M}$ after 72 hours of incubation with SHSY5Y human neuroblastoma cells (Fig. 6). Compound $\mathbf{2 b}$ was insoluble under the assay conditions and could not be tested.

\section{The binding properties of compound}

Compounds $\mathbf{2 c}, \mathbf{2 e}$ and $\mathbf{2 h}$ were further investigated by generating full concentration-dependent curves (Fig. 7). All three compounds showed total displacement of the radioligand $\left[{ }^{3} \mathrm{H}\right]$ CP55,940 to both cannabinoid receptors with the most potent compound (2h) displaying a $K_{\mathrm{i}}$ value (calculated applying the Cheng-Prusoff equation) of $120 \mathrm{nM}$ towards the $\mathrm{CB}_{2}$ receptor and a 6-fold selectivity $v s$. the $\mathrm{CB}_{1}$ receptor $\left(K_{\mathrm{i}}\right.$ value of 750 nM) (Fig. 7). The highest affinity shown by compound $\mathbf{2 h}$ could be explained by an interaction with the receptor similar to other non-classical synthetic cannabinoids (SR141716A (rimonabant), JWH015 and LY320135 shown in Fig. 4), consi- 
<smiles>CCCCC/C=C\C/C=C\C/C=C\C/C=C\CCCC(=O)NCCO</smiles>

AEA

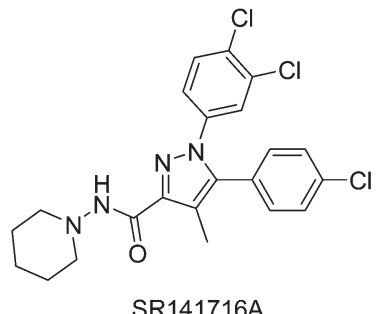

SR141716A<smiles>CCCCC/C=C\C/C=C\C/C=C\C/C=C\CCCC(=O)OC(CO)CO</smiles>

2-AG

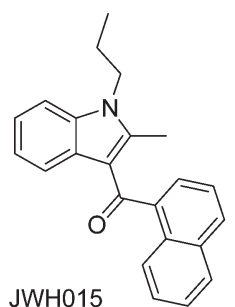

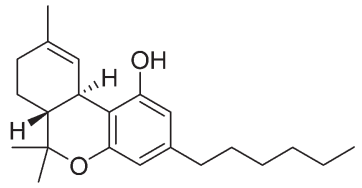

$\Delta^{9}-\mathrm{THC}$<smiles>COc1ccc(-c2oc3cc(OC)ccc3c2C(=O)c2ccc(C#N)cc2)cc1</smiles>

LY320135

Fig. 5 Endogenous (AEA and 2-AG) and natural ( $\left.\Delta^{9}-\mathrm{THC}\right)$ and synthetic (SR141716A, JWH015 and LY320135) cannabinoid receptor ligands.
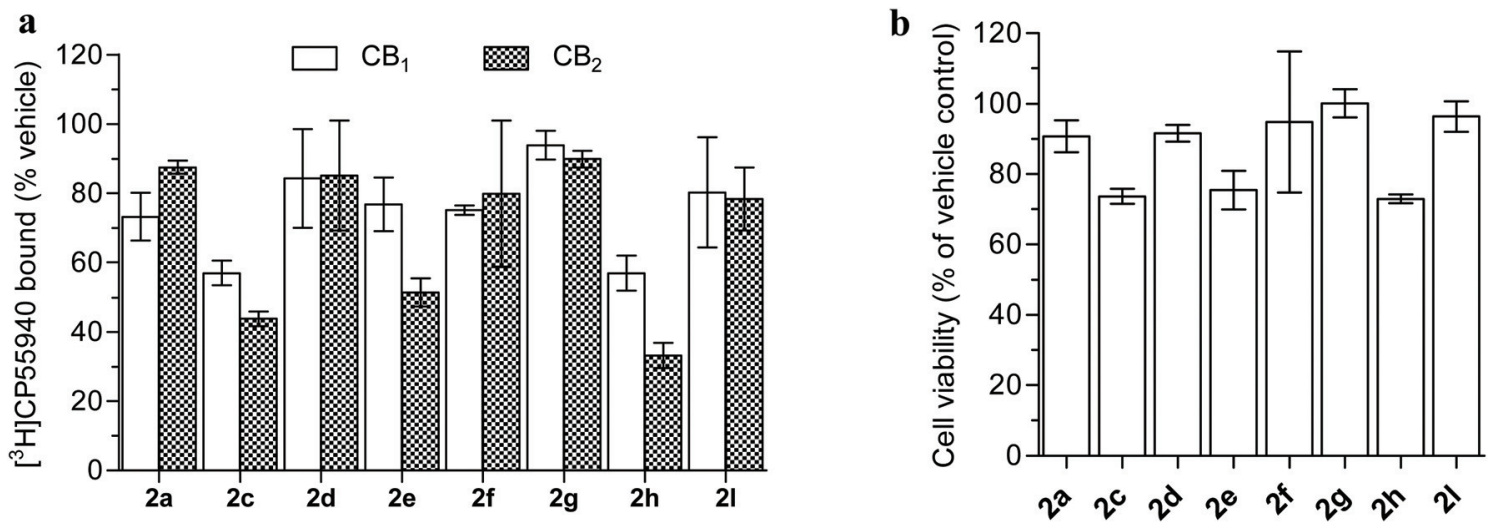

Fig. 6 (a) Binding properties of compounds $2 a, 2 c, 2 d-h, l$ tested at the concentration of $1 \mu \mathrm{M}$ to $\mathrm{CB}_{1}$ and $\mathrm{CB}_{2}$ receptors $(N=3: n=6$, data shown are mean \pm standard deviation); (b) cytotoxicity of the same compounds tested at $10 \mu \mathrm{M}$ on SHSY5Y cells (SRB method, ${ }^{22} 72$ hours of incubation $N=$ 2-3: $n=4-6$, data shown are mean \pm standard deviation).

dering quite an effective spatial overlay of $2 \mathbf{h}$ with these three known $\mathrm{CB}_{1} / \mathrm{CB}_{2}$ ligands, especially with LY320135, suggesting potentially similar functional signaling by our trans-diaryl indanes (Fig. 8). ${ }^{23}$

The trifluoromethyl indanes $\mathbf{2 a}, \mathbf{2 c}$ and $\mathbf{2 d - h}, \mathbf{l}$ were also tested for potential inhibition of the key components of the endocannabinoid system such as the hydrolytic enzymes fatty acid amide hydrolase (FAAH) for AEA and monoacylglycerol lipase (MAGL) and $\alpha / \beta$ hydrolase domain (ABHDs) for $2-\mathrm{AG}$, the oxidative enzyme cyclooxygenase-2 for 2-AG and arachidonic acid and the putative endocannabinoid membrane transporter. $^{24}$ Interestingly, the compounds showed negligible effects on all these targets (see ESI $\dagger$ ), clearly indicating that 2c, $2 \mathbf{e}$ and $2 \mathbf{h}$ selectively bind to cannabinoid receptors, particularly $\mathrm{CB}_{2}$ receptors which are highly promising pharma- cological targets for treating inflammatory and neuropathic pain $^{25}$ and neurodegenerative diseases. ${ }^{26}$

\section{Conclusions}

Novel efficient stereoselective synthesis of trans-1,3-diaryl-1-trifluoromethyl indanes was developed on the basis of superelectrophilic activation of 4-aryl-1,1,1-trufluorobut-3-en-2-ones and subsequent reaction with arenes. The reaction intermediates, O-protonated and O,C-diprotonated forms of 4-aryl1,1,1-trufluorobut-3-en-2-ones have been studied by ${ }^{1} \mathrm{H},{ }^{13} \mathrm{C}$, ${ }^{19} \mathrm{~F}$ NMR, and DFT calculations. Both of these cations take part in the reaction, depending on electrophilicity of the cations and electron donating properties of arenes. 

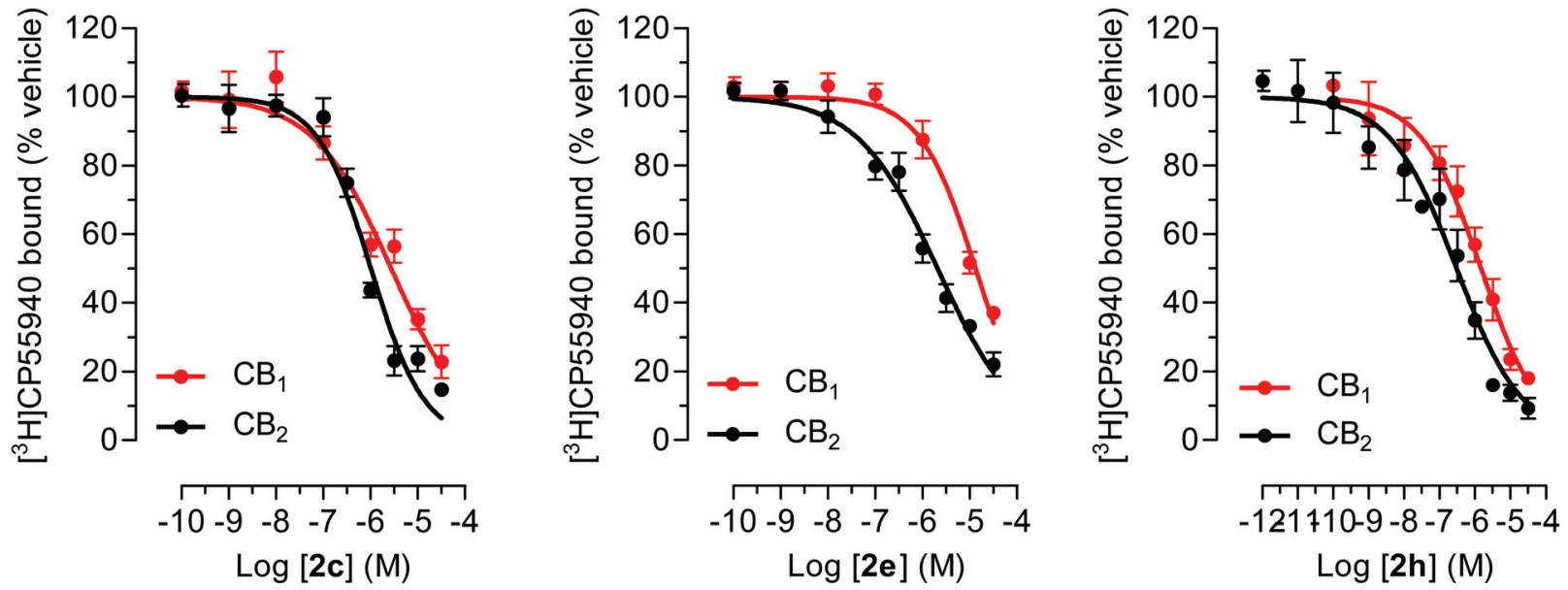

\begin{tabular}{|c|c|c|}
\hline & \multicolumn{2}{|c|}{ Ki value (mean and $95 \%, \mathrm{CI}) \mu \mathrm{M}$} \\
\hline & $h \mathrm{CB}_{1}$ & $h \mathrm{CB}_{2}$ \\
\hline $2 c$ & $1.35(0.91-2.05)$ & $0.55(0.42-0.73)$ \\
\hline $2 \mathrm{e}$ & $6.55(4.92-8.71)$ & $1.19(0.75-1.68)$ \\
\hline $2 \mathbf{h}$ & $0.75(0.48-1.15)$ & $0.12(0.07-0.20)$ \\
\hline
\end{tabular}

Fig. 7 Concentration-dependent binding curves and $K_{\mathrm{i}}$ values calculated for compounds $2 \mathrm{c}, 2 \mathrm{e}$ and $2 \mathrm{~h}(N=3-6: n=9-18$, data shown are mean \pm standard deviation for the binding curves and mean and $95 \%$ confidence interval for $K_{\mathrm{i}}$ values).
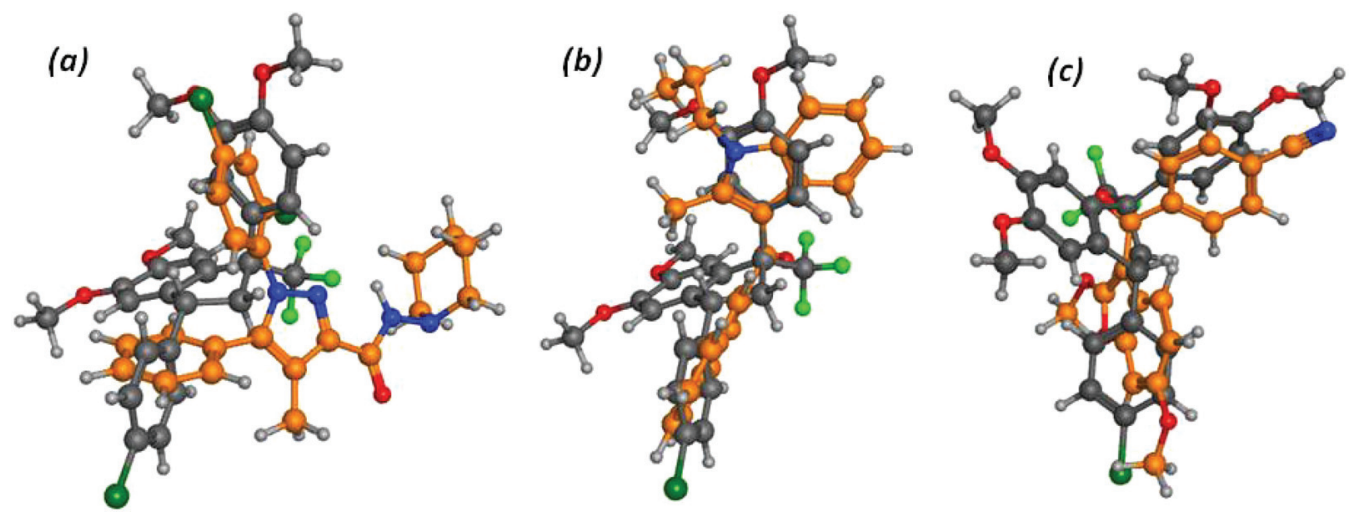

Fig. 8 Spatial overlay of the structure of compound 2h (shown in grey) with (a) SR141716A, (b) JWH015 and (c) LY320135 - all shown in orange.

Among the novel trans-1,3-diaryl-1-trifluoromethyl indanes obtained in this work, three moderately potent ligands of cannabinoid receptors have been identified. The most potent compound (2h) displayed a $120 \mathrm{nM}$ affinity toward $\mathrm{CB}_{2}$ recep- tor and a 6-fold selectivity $v s$. $\mathrm{CB}_{1}$ receptor. In the absence of cytotoxicity and any effect on the other key components of the endocannabinoid system, the new trans-1,3-diaryl-1-trifluoromethyl indane scaffold clearly has a value for the design on 
selective modulators of cannabinoid (in particular, $\mathrm{CB}_{2}$ ) receptors.

\section{Experimental}

The NMR spectra of solutions of compounds in $\mathrm{CDCl}_{3}$ were recorded on Bruker AVANCE III 400 (at 400, 376 and $100 \mathrm{MHz}$ for ${ }^{1} \mathrm{H},{ }^{19} \mathrm{~F}$ and ${ }^{13} \mathrm{C}$ NMR spectra respectively) or Bruker DPX 300 (at 300 and $75 \mathrm{MHz}$ for ${ }^{1} \mathrm{H}$ and ${ }^{13} \mathrm{C}$ NMR spectra respectively) spectrometers at $25{ }^{\circ} \mathrm{C}$. The residual proton-solvent peak $\mathrm{CDCl}_{3}(\delta 7.26 \mathrm{ppm})$ for ${ }^{1} \mathrm{H}$ NMR spectra and the carbon signal of $\mathrm{CDCl}_{3}(\delta 77.0 \mathrm{ppm})$ for ${ }^{13} \mathrm{C}$ NMR spectra were used as references. NMR experiments in the superacids $\mathrm{TfOH}$ or $\mathrm{FSO}_{3} \mathrm{H}$ were performed on a Bruker AVANCE III spectrometer (at 500, 476 and $125 \mathrm{MHz}$ for ${ }^{1} \mathrm{H},{ }^{19} \mathrm{~F}$ and ${ }^{13} \mathrm{C}$ NMR spectra respectively). NMR spectra in superacids were referenced to the signal of $\mathrm{CH}_{2} \mathrm{Cl}_{2}$ added as an internal standard: $\delta 5.32 \mathrm{ppm}$ for ${ }^{1} \mathrm{H}$ NMR spectra, and $\delta 53.84 \mathrm{ppm}$ for ${ }^{13} \mathrm{C}$ NMR spectra. HRMS was carried out on instruments Bruker maXis HRMS-ESI-QTOF and Varian 902-MS MALDI Mass Spectrometer. Chromatomass-spectrometry data were obtained using Shimadzu QP-2010 Ultra with a SPB-1 SULFUR capillary column (30 $\mathrm{m} \times$ $0.32 \mathrm{~mm}$ ), thickness of the stationary phase being $1.25 \mu \mathrm{m}$. The preparative reactions were monitored by thin-layer chromatography carried out on silica gel plates (Alugram SIL G/UV-254), using UV light for detection. Preparative column chromatography was performed on silica gel 60 Merck with hexane-ethyl acetate mixture elution.

For single crystal X-ray diffraction experiments, crystals of all compounds were fixed on a micro mount and placed on an Agilent Technologies Excalibur Eos diffractometer using monochromated MoK $\alpha$ radiation (2a, 2b) and on Agilent Technologies SuperNova using a monochromated CuK $\alpha$ $(\mathbf{2 e}, \mathbf{2 g}, 2 \mathbf{h})$ (Oxford Diffraction) diffractometer and measured at a temperature of $100 \mathrm{~K}$. The structures have been solved by direct methods SHELXS and refined for unique reflections with $\left|F_{\mathrm{O}}\right| \geq 4 \sigma_{\mathrm{F}}$ by means of the SHELXL program ${ }^{27}$ incorporated in the OLEX2 program package. ${ }^{28}$ The carbon-bound $\mathrm{H}$ atoms were placed in calculated positions and were included in the refinement in the 'riding' model approximation, with $U_{\text {iso }}(\mathrm{H})$ set to $1.5 U_{\text {eq }}(\mathrm{C})$ and $\mathrm{C}-\mathrm{H} 0.96 \AA$ for the $\mathrm{CH}_{3}$ groups, $U_{\text {iso }}(\mathrm{H})$ set to $1.2 U_{\text {eq }}(\mathrm{C})$ and $\mathrm{C}-\mathrm{H} 0.97 \AA$ for the $\mathrm{CH}_{2}$ groups, $U_{\text {iso }}(\mathrm{H})$ set to $1.2 U_{\text {eq }}(\mathrm{C})$ and $\mathrm{C}-\mathrm{H} 0.93 \AA$ for the $\mathrm{CH}$ groups. CCDC 1047066 (2a), CCDC 1047331 (2b), CCDC 1047468 (2e), CCDC 1047315 (2g), CCDC 1047593 (2h) contain the supplementary crystallographic data.

All computations has been carried out at the DFT/HF hybrid level of theory using Becke's three-parameter hybrid exchange functional in combination with the gradient-corrected correlation functional of Lee, Yang, and Parr (B3LYP) by using GAUSSIAN 2003 program packages. ${ }^{29}$ The geometry optimization was performed using the $6-311+G(2 d, 2 p)$ basis set. The Hessian matrix was calculated analytically for the optimized structures in order to prove the location of correct minima (no imaginary frequencies) and to estimate the thermodynamic parameters. Enthalpies and Gibbs free energies were calculated at $25{ }^{\circ} \mathrm{C}$.

Starting 4-aryl-1,1,1-trufluorobut-3-en-2-ones 1a-i were prepared according to the literature procedures. ${ }^{1 b_{f} f-h}$

\section{General procedure for reaction of compounds 1a-g with arenes in superacids $\mathrm{CF}_{3} \mathrm{SO}_{3} \mathrm{H}$ or $\mathrm{FSO}_{3} \mathrm{H}$}

Synthesis of compounds $2 \mathrm{a}-\mathbf{n}$, cis-2a, 3a,b. $\mathrm{CF}_{3}$-enone $\mathbf{1 a}-\mathrm{g}$ $\left(0.23 \mathrm{mmol}\right.$ ) was added to a mixture of $\mathrm{TfOH}\left(\right.$ at $20{ }^{\circ} \mathrm{C}$ ) $(1-2 \mathrm{~mL})$ or $\mathrm{FSO}_{3} \mathrm{H}$ (at -80 to $\left.-60{ }^{\circ} \mathrm{C}\right)\left(1 \mathrm{~mL}\right.$, co-solvents $\mathrm{SO}_{2}$ or $\mathrm{CH}_{2} \mathrm{Cl}_{2}$ ) with benzene $(0.3 \mathrm{ml})$ or another arene $(1 \mathrm{mmol})$. The reaction mixture was magnetically stirred for $1-2 \mathrm{~h}$. Then in the case of $\mathrm{TfOH}$ the mixture was poured into ice water $(30 \mathrm{~mL})$ and extracted with chloroform $(2 \times 40 \mathrm{~mL})$. The extracts were combined, washed with water, a saturated aqueous solution of $\mathrm{NaHCO}_{3}$, water again, and dried over $\mathrm{Na}_{2} \mathrm{SO}_{4}$. The solvent was distilled off under reduced pressure, and the residue was recrystallized from methanol or subjected to chromatographic separation on silica gel using hexaneethyl acetate mixtures $(20: 1$ to $10: 1)$ as an eluent. For $\mathrm{FSO}_{3} \mathrm{H}$ the reaction mixture was quenched with frozen $-80{ }^{\circ} \mathrm{C}$ concentrated aqueous $\mathrm{HCl}(10 \mathrm{~mL})$, diluted with water $(20 \mathrm{ml})$, then extracted and worked up as described above. Yields of the obtained compounds are given in Table 1 and Schemes 2, 3 and 6.

(1RS,3RS)-1-Trifluoromethyl-1,3-diphenylindane (2a). Yield $65 \mathrm{mg}, 84 \%$. Colorless solid, mp 106-108 ${ }^{\circ} \mathrm{C}(\mathrm{MeOH}) .{ }^{1} \mathrm{H}$ NMR $\left(\mathrm{CDCl}_{3}, 400 \mathrm{MHz}\right) \delta$, ppm: $2.80(\mathrm{dd}, J=11.2 \mathrm{~Hz}, 12.5 \mathrm{~Hz}, 1 \mathrm{H})$, $3.05(\mathrm{dd}, J=6.8 \mathrm{~Hz}, 12.5 \mathrm{~Hz}, 1 \mathrm{H}), 4.09(\mathrm{dd}, J=11.2 \mathrm{~Hz}, 6.8 \mathrm{~Hz}$, $1 \mathrm{H}), 6.95(\mathrm{~d}, J=7.5 \mathrm{~Hz}, 1 \mathrm{H}), 7.21(\mathrm{~d}, J=6.8 \mathrm{~Hz}, 2 \mathrm{H}), 7.29(\mathrm{~d}, J=$ $7.2 \mathrm{~Hz}, 1 \mathrm{H}), 7.25-7.38(\mathrm{~m}, 8 \mathrm{H}), 7.40(\mathrm{t}, J=7.5 \mathrm{~Hz}, 1 \mathrm{H}), 7.64(\mathrm{~d}$, $1 \mathrm{H}, J=7.9 \mathrm{~Hz}) .{ }^{13} \mathrm{C} \mathrm{NMR}\left(\mathrm{CDCl}_{3}, 100 \mathrm{MHz}\right) \delta, \mathrm{ppm}: 46.9(\mathrm{CH})$, $48.3\left(\mathrm{CH}_{2}\right), 60.8\left(\mathrm{q}, \underline{\mathrm{C}}-\mathrm{CF}_{3}, J=26.4 \mathrm{~Hz}\right), 125.7,125.9(\mathrm{~d}, J=$ $1.3 \mathrm{~Hz}), 127.17,127.20,127.6\left(\mathrm{q}, \mathrm{CF}_{3}, J=281.5 \mathrm{~Hz}\right), 128.0$, 128.5, $128.6(2 \mathrm{CH}), 128.8,129.0,137.5,140.7$ (d, $J=1.4 \mathrm{~Hz})$, 142.8, 147.5. ${ }^{19} \mathrm{~F}$ NMR $\left(\mathrm{CDCl}_{3}, 376 \mathrm{MHz}\right) \delta$, ppm: $-69.16(\mathrm{~s}$, $\mathrm{CF}_{3}$ ). MS (GC-MS, EI), $m / z\left(I_{\text {rel. }}, \%\right)-338 \mathrm{M}^{+}$(3), 260 (100), 191 (50). HRMS: $\mathrm{C}_{22} \mathrm{H}_{17} \mathrm{~F}_{3}$ found $338.1285 \mathrm{M}^{+}$; calcd 338.1282.

\section{(1SR,3RS)-1-Trifluoromethyl-1,3-diphenylindane (cis-2a).} Obtained as a 1:1 mixture with indane 2a. Yield $25 \mathrm{mg}, 80 \%$. ${ }^{1} \mathrm{H}$ NMR $\left(\mathrm{CDCl}_{3}, 400 \mathrm{MHz}\right) \delta$, ppm: $2.52(\mathrm{dd}, J=8.4 \mathrm{~Hz}$, $14.4 \mathrm{~Hz}, 1 \mathrm{H}), 3.43(\mathrm{dd}, J=8.4 \mathrm{~Hz}, 14.4 \mathrm{~Hz}, 1 \mathrm{H}), 4.63(\mathrm{t}, J=$ $8.4 \mathrm{~Hz}, 1 \mathrm{H}), 7.08(\mathrm{~d}, J=7.0 \mathrm{~Hz}, 1 \mathrm{H}), 7.15(\mathrm{~d}, J=7.1 \mathrm{~Hz}, 2 \mathrm{H})$, 7.20-7.24 (m, 1H), 7.25-7.35 (m, 8H), $7.47(\mathrm{~d}, J=7.7 \mathrm{~Hz}, 2 \mathrm{H})$. ${ }^{13} \mathrm{C} \mathrm{NMR}\left(\mathrm{CDCl}_{3}, 100 \mathrm{MHz}\right) \delta$, ppm: $48.1\left(\mathrm{CH}_{2}\right), 49.9(\mathrm{CH}), 61.7$ (q, $\left.\underline{\mathrm{C}}-\mathrm{CF}_{3}, J=25.3 \mathrm{~Hz}\right), 127.6\left(\mathrm{q}, \mathrm{CF}_{3}, J=281 \mathrm{~Hz}\right), 141.2$, 141.51, 141.52, 144.4, 148.4. ${ }^{19} \mathrm{~F}$ NMR $\left(\mathrm{CDCl}_{3}, 376 \mathrm{MHz}\right)$ $\delta$, ppm: $-69.36\left(\mathrm{~s}, \mathrm{CF}_{3}\right)$. MS (GC-MS, EI), $m / z\left(I_{\text {rel. }}, \%\right)-338 \mathrm{M}^{+}$ (100), 269 (100), 260 (90), 191 (100). HRMS: $\mathrm{C}_{22} \mathrm{H}_{17} \mathrm{~F}_{3}$ found $338.1285 \mathrm{M}^{+}$; calcd 338.1282.

(1RS,3RS)-1-Trifluoromethyl-5,6-dimethyl-1-(3,4-dimethylphenyl)3-phenylindane (2b). Yield $80 \mathrm{mg}, 77 \%$. Colorless solid, $\mathrm{mp}$ 106-108 ${ }^{\circ} \mathrm{C}(\mathrm{MeOH}) .{ }^{1} \mathrm{H}$ NMR $\left(\mathrm{CDCl}_{3}, 300 \mathrm{MHz}\right) \delta$, ppm: 2.25 $\left(\mathrm{s}, 3 \mathrm{H}, \mathrm{CH}_{3}\right), 2.28\left(\mathrm{~s}, 6 \mathrm{H}, 2 \mathrm{CH}_{3}\right), 2.38\left(\mathrm{~s}, 3 \mathrm{H}, \mathrm{CH}_{3}\right), 2.74(\mathrm{dd}$, $1 \mathrm{H}, J=12.5 \mathrm{~Hz}, 11 \mathrm{~Hz}), 3.00(\mathrm{dd}, 1 \mathrm{H}, J=6.5 \mathrm{~Hz}, 12.5 \mathrm{~Hz}), 4.06$ $(\mathrm{dd}, 1 \mathrm{H}, J=6.5 \mathrm{~Hz}, 11 \mathrm{~Hz}), 6.72(\mathrm{~s}, 1 \mathrm{H}), 7.01-7.12(\mathrm{~m}, 2 \mathrm{H}), 7.17$ 
(s, 1H), 7.22-7.25 (m, 2H), 7.29-7.36 (m, 4H). ${ }^{13} \mathrm{C} \mathrm{NMR}\left(\mathrm{CDCl}_{3}\right.$, $75 \mathrm{MHz}) \delta$, ppm: $19.3\left(\mathrm{CH}_{3}\right), 19.9\left(\mathrm{CH}_{3}\right), 20.1\left(\mathrm{CH}_{3}\right), 47.0\left(\mathrm{CH}_{2}\right)$, $47.8(\mathrm{CH}), 60.1\left(\mathrm{q}, \underline{\mathrm{C}}-\mathrm{CF}_{3}, J=25 \mathrm{~Hz}\right), 125.8,126.0,126.3,126.5$, 126.8, 128.5, 128.6, 129.5, 129.55, 129.6 (q, $\mathrm{CF}_{3}, J=275 \mathrm{~Hz}$ ), 135.2, 135.3, 136.2, 136.4, 138.4, 143.2, 144.8. ${ }^{19} \mathrm{~F} \mathrm{NMR}\left(\mathrm{CDCl}_{3}\right.$, $470 \mathrm{MHz}) \delta$, ppm: $-69.19\left(\mathrm{~s}, \mathrm{CF}_{3}\right)$. MS (GC-MS, EI), $m / z\left(I_{\text {rel. }}\right.$, \%) - 394 (5) $[\mathrm{M}]^{+}, 325$ (30), 289 (100), 219 (34). HRMS: $\mathrm{C}_{26} \mathrm{H}_{25} \mathrm{~F}_{3}$ found $394.1911 \mathrm{M}^{+}$; calcd 394.1908.

(1RS,3RS)-1-Trifluoromethyl-5,6-dimetoxy-1-(3,4-dimetoxyphenyl)3-phenylindane (2c). Yield $77 \mathrm{mg}, 75 \%$. Colorless solid, mp 104-108 ${ }^{\circ} \mathrm{C}(\mathrm{MeOH}) .{ }^{1} \mathrm{H} \mathrm{NMR}\left(\mathrm{CDCl}_{3}, 500 \mathrm{MHz}\right) \delta$, ppm: 2.68 (dd, $1 \mathrm{H}, J=11 \mathrm{~Hz}, 12.5 \mathrm{~Hz}$ ), 2.90 (dd, 1H, $12.5 \mathrm{~Hz}, 7 \mathrm{~Hz}$ ), 3.72 $\left(\mathrm{s}, 3 \mathrm{H}, \mathrm{OCH}_{3}\right), 3.78\left(\mathrm{~s}, 3 \mathrm{H}, \mathrm{OCH}_{3}\right), 3.84\left(\mathrm{~s}, 3 \mathrm{H}, \mathrm{OCH}_{3}\right), 3.91(\mathrm{~s}$, $\left.3 \mathrm{H}, \mathrm{OCH}_{3}\right), 4.04(\mathrm{dd}, 1 \mathrm{H}, J=7 \mathrm{~Hz}, 11 \mathrm{~Hz}), 6.40(\mathrm{~s}, 1 \mathrm{H})$, 6.70-6.78 (m, 2H), $6.88(\mathrm{~s}, 1 \mathrm{H}), 7.03(\mathrm{~s}, 1 \mathrm{H}), 7.18(\mathrm{~d}, 2 \mathrm{H}, J=$ $7 \mathrm{~Hz}), 7.22-7.25(\mathrm{~m}, 1 \mathrm{H}), 7.31$ (t, $2 \mathrm{H}, J=7.4 \mathrm{~Hz}) .{ }^{13} \mathrm{C} \mathrm{NMR}$ $\left(\mathrm{CDCl}_{3}, 125 \mathrm{MHz}\right) \delta$, ppm: $47.8\left(\mathrm{CH}_{2}\right), 48.2(\mathrm{CH}), 55.82(\mathrm{OMe})$, $55.83(\mathrm{OMe}), 56.0(\mathrm{OMe}), 56.3(\mathrm{OMe}), 60.2$ (q, $\underline{\mathrm{C}}-\mathrm{CF}_{3}$, $J=26 \mathrm{~Hz}), 107.9,108.1,110.6,111.7,121.0,127.0,128.4,128.7$, 128.8, 130.5, 132.4, 133.4 (q, $\mathrm{CF}_{3}, J=275 \mathrm{~Hz}$ ), 139.6, 143.1, 148.56, 148.62 (2C), 150.0. ${ }^{19} \mathrm{~F} \mathrm{NMR}\left(\mathrm{CDCl}_{3}, 470 \mathrm{MHz}\right) \delta$, ppm: $-69.22\left(\mathrm{~s}, \mathrm{CF}_{3}\right)$. MS (GC-MS, EI), $m / z\left(I_{\text {rel. }}, \%\right)-458 \mathrm{M}^{+}(32)$, 389 (33), 320 (100). HRMS: $\mathrm{C}_{26} \mathrm{H}_{25} \mathrm{~F}_{3} \mathrm{O}_{4}$ found $458.1708 \mathrm{M}^{+}$; calcd 458.1705 .

(1RS,3RS)-1-Trifluoromethyl-6-methyl-1,3-diphenylindane (2d). Yield $31 \mathrm{mg}, 35 \%$. Colorless solid, mp 102-105 ${ }^{\circ} \mathrm{C}(\mathrm{MeOH}) .{ }^{1} \mathrm{H}$ $\mathrm{NMR}\left(\mathrm{CDCl}_{3}, 400 \mathrm{MHz}\right) \delta$, ppm: 2.38 (s, 3H, $\left.\mathrm{CH}_{3}\right), 2.68$ (dd, $1 \mathrm{H}, J=12.5 \mathrm{~Hz}, 11 \mathrm{~Hz}), 2.93(\mathrm{dd}, 1 \mathrm{H}, J=6.8 \mathrm{~Hz}, 12.5 \mathrm{~Hz}), 3.96$ $(\mathrm{dd}, 1 \mathrm{H}, J=6.8 \mathrm{~Hz}, 11 \mathrm{~Hz}), 6.75(\mathrm{~d}, 1 \mathrm{H}, J=7.8 \mathrm{~Hz}), 7.07(\mathrm{~d}, 1 \mathrm{H}$, $J=7.8 \mathrm{~Hz}), 7.11-7.14(\mathrm{~m}, 9 \mathrm{H}), 7.18(\mathrm{~s}, 1 \mathrm{H}), 7.34(\mathrm{~s}, 1 \mathrm{H}) .{ }^{13} \mathrm{C}$ NMR $\left(\mathrm{CDCl}_{3}, 100 \mathrm{MHz}\right) \delta$, ppm: $21.7\left(\mathrm{CH}_{3}\right), 47.2\left(\mathrm{CH}_{2}\right), 47.9$ $(\mathrm{CH}), 60.8$ (q, $\left.\mathrm{C}-\mathrm{CF}_{3}, J=29 \mathrm{~Hz}\right), 124.7,125.4,126.3$ (q, $\left.\mathrm{CHCCCF}_{3}, J=1.1 \mathrm{~Hz}\right), 127.1,128.0,128.5,128.5\left(\mathrm{q}, \mathrm{CF}_{3}, J=\right.$ $256 \mathrm{~Hz}), 128.6$ (2CH), 128.8, 129.8, 137.0, 137.7, 140.8, 143.1, 144.6. ${ }^{19} \mathrm{~F} \mathrm{NMR}\left(\mathrm{CDCl}_{3}, 376 \mathrm{MHz}\right) \delta$, ppm: $-69.01\left(\mathrm{~s}, \mathrm{CF}_{3}\right) . \mathrm{MS}$ (GC-MS, EI), $m / z\left(I_{\text {rel. }}, \%\right)-352 \mathrm{M}^{+}$(15), 274 (100), 205 (40). HRMS: $\mathrm{C}_{23} \mathrm{H}_{19} \mathrm{~F}_{3}$ found 352.1441 $\mathrm{M}^{+}$; calcd 352.1439.

(1RS,3RS)-3-(4-Chlorophenyl)-1-trifluoromethyl-1-phenylindane (2e). Yield $53 \mathrm{mg}, 80 \%$. Colorless solid, mp 109-112 ${ }^{\circ} \mathrm{C}$ $(\mathrm{MeOH}) .{ }^{1} \mathrm{H} \mathrm{NMR}\left(\mathrm{CDCl}_{3}, 400 \mathrm{MHz}\right) \delta$, ppm: $2.72(\mathrm{dd}, 1 \mathrm{H}, J=$ $12.5 \mathrm{~Hz}, 11.2 \mathrm{~Hz}$ ), 3.03 (dd, $1 \mathrm{H}, J=12.5 \mathrm{~Hz}, 6.8 \mathrm{~Hz}$ ), 4.06 (dd, $1 \mathrm{H}, J=11.2 \mathrm{~Hz}, 6.8 \mathrm{~Hz}), 6.93(\mathrm{~d}, 1 \mathrm{H}, J=7.6 \mathrm{~Hz}), 7.14(\mathrm{~d}, 2 \mathrm{H}, J=$ $8.4 \mathrm{~Hz}), 7.36-7.28(\mathrm{~m}, 8 \mathrm{H}), 7.40(\mathrm{t}, 1 \mathrm{H}, J=7.5 \mathrm{~Hz}), 7.63(\mathrm{~d}, 1 \mathrm{H}$, $J=7.6 \mathrm{~Hz}) \cdot{ }^{13} \mathrm{C} \mathrm{NMR}\left(\mathrm{CDCl}_{3}, 100 \mathrm{MHz}\right) \delta, \mathrm{ppm}: 46.9\left(\mathrm{q}, \mathrm{CH}_{2}\right.$, $J=1.3 \mathrm{~Hz}), 47.7(\mathrm{CH}), 60.8\left(\mathrm{q}, \underline{\mathrm{C}}-\mathrm{CF}_{3}, J=25 \mathrm{~Hz}\right), 125.5,126.0$ $(J 1.2 \mathrm{~Hz}), 127.4,127.6\left(\mathrm{q}, \mathrm{CF}_{3}, \bar{J}=281 \mathrm{~Hz}\right), 128.1,128.5,128.6$ (q, $J=0.8 \mathrm{~Hz}), 129.0,129.9,133.0,137.3,140.7(\mathrm{q}, J=1.3 \mathrm{~Hz})$, 141.9, 147.0. ${ }^{19} \mathrm{~F} \mathrm{NMR}\left(\mathrm{CDCl}_{3}, 376 \mathrm{MHz}\right) \delta$, ppm: -69.19 (s, $\mathrm{CF}_{3}$ ). MS (GC-MS, EI), $m / z$ ( $\left.I_{\text {rel. }}, \%\right)-372 \mathrm{M}^{+}$(15), 337 (15), 303 (10), 294 (100). HRMS: $\mathrm{C}_{22} \mathrm{H}_{16} \mathrm{~F}_{3} \mathrm{Cl}$ found $372.0893 \mathrm{M}^{+}$; calcd 372.0893 .

(1RS,3RS)-3-(4-Chlorophenyl)-1-trifluoromethyl-5, 6-dimethyl-1(3,4-dimethylphenyl)indane (2f). Yield $50 \mathrm{mg}, 57 \%$. Colorless solid, mp 113-115 ${ }^{\circ} \mathrm{C}(\mathrm{MeOH}) .{ }^{1} \mathrm{H}$ NMR $\left(\mathrm{CDCl}_{3}, 300 \mathrm{MHz}\right) \delta$, ppm: $2.23\left(\mathrm{~s}, 3 \mathrm{H}, \mathrm{CH}_{3}\right), 2.25\left(\mathrm{~s}, 6 \mathrm{H}, 2 \mathrm{CH}_{3}\right), 2.36\left(\mathrm{~s}, 3 \mathrm{H}, \mathrm{CH}_{3}\right)$, 2.65 (dd, $1 \mathrm{H}, J=12.4 \mathrm{~Hz}, 10.6 \mathrm{~Hz}), 2.96$ (dd, $1 \mathrm{H}, J=10.6 \mathrm{~Hz}$,
$6.5 \mathrm{~Hz}), 4.02(\mathrm{dd}, 1 \mathrm{H}, J=6.5 \mathrm{~Hz}, 10.6 \mathrm{~Hz}), 6.67(\mathrm{~s}, 1 \mathrm{H}), 7.00(\mathrm{~d}$, $1 \mathrm{H}, J=8.0 \mathrm{~Hz}), 7.07$ (d, $1 \mathrm{H}, J=8.0 \mathrm{~Hz}), 7.14(\mathrm{~m}, 3 \mathrm{H}), 7.30$ (d, $2 \mathrm{H}, J=8.4 \mathrm{~Hz}), 7.36 \mathrm{br}(\mathrm{s}, 1 \mathrm{H}) .{ }^{13} \mathrm{C} \mathrm{NMR}\left(\mathrm{CDCl}_{3}, 100 \mathrm{MHz}\right)$ $\delta$, ppm: $19.5\left(\mathrm{CH}_{3}\right), 20.1\left(2 \mathrm{CH}_{3}\right), 20.3\left(\mathrm{CH}_{3}\right), 47.2\left(\mathrm{~d}, \mathrm{CH}_{2}, J=\right.$ $0.8 \mathrm{~Hz}), 47.4(\mathrm{CH}), 60.3\left(\mathrm{q}, \underline{\mathrm{C}}-\mathrm{CF}_{3}, J=26.2 \mathrm{~Hz}\right), 126.1,126.3$ (d, $J=4.9 \mathrm{~Hz}), 126.8(\mathrm{~d}, J=0.7 \mathrm{~Hz}), 127.8\left(\mathrm{q}, \mathrm{CF}_{3}, J=282 \mathrm{~Hz}\right)$, 128.9, 126.8, 129.6, 130.0, 132.7, 135.1, 135.8, 136.46, 136.63, 137.5, 141.9, 144.5. ${ }^{19} \mathrm{~F} \mathrm{NMR}\left(\mathrm{CDCl}_{3}, 376 \mathrm{MHz}\right) \delta$, ppm: -69.22 (s, $\mathrm{CF}_{3}$ ). MS (GC-MS, EI), $m / z\left(I_{\text {rel. }}, \%\right)-428 \mathrm{M}^{+}$(10), 359 (7), 322 (100), 253 (12). HRMS: $\mathrm{C}_{26} \mathrm{H}_{24} \mathrm{~F}_{3} \mathrm{Cl}$ found 428.1514 $\mathrm{M}^{+}$; calcd 428.1519 .

(1RS,3RS)-3-(4-Chlorophenyl)-1-trifluoromethyl-4, 6-dimethyl-1(3,5-dimethylphenyl)indane (2g). Yield $46 \mathrm{mg}, 54 \%$. Colorless solid, mp 103-105 ${ }^{\circ} \mathrm{C}(\mathrm{MeOH}) .{ }^{1} \mathrm{H} \mathrm{NMR}\left(\mathrm{CDCl}_{3}, 300 \mathrm{MHz}\right) \delta$, ppm: $1.71\left(\mathrm{~s}, 3 \mathrm{H}, \mathrm{CH}_{3}\right), 2.27\left(\mathrm{~s}, 6 \mathrm{H}, 2 \mathrm{CH}_{3}\right), 2.41\left(\mathrm{~s}, 3 \mathrm{H}, \mathrm{CH}_{3}\right)$, $2.60(\mathrm{dd}, 1 \mathrm{H}, J=13.2 \mathrm{~Hz}, 9.8 \mathrm{~Hz}), 3.01(\mathrm{dd}, 1 \mathrm{H}, J=13.2 \mathrm{~Hz}$, $7.6 \mathrm{~Hz}), 4.15(\mathrm{t}, 1 \mathrm{H}, J=8.6 \mathrm{~Hz}), 6.85(\mathrm{~s}, 2 \mathrm{H}), 6.96(\mathrm{~s}, 1 \mathrm{H})$, $6.97(\mathrm{~s}, 1 \mathrm{H}), 7.08(\mathrm{~d}, 2 \mathrm{H}, J=8.2 \mathrm{~Hz}), 7.22(\mathrm{~s}, 1 \mathrm{H}), 7.27(\mathrm{~d}, 1 \mathrm{H}$, $J=8.2 \mathrm{~Hz}) \cdot{ }^{13} \mathrm{C} \mathrm{NMR}\left(\mathrm{CDCl}_{3}, 100 \mathrm{MHz}\right) \delta$, ppm: $19.9\left(\mathrm{CH}_{3}\right)$, $21.5\left(\mathrm{CH}_{3}\right), 21.7\left(2 \mathrm{CH}_{3}\right), 47.5(\mathrm{CH}), 48.0\left(\mathrm{~d}, \mathrm{CH}_{2}, J=1 \mathrm{~Hz}\right), 60.7$ (q, $\left.\underline{\mathrm{C}}-\mathrm{CF}_{3}, J=26.2 \mathrm{~Hz}\right), 124.3(\mathrm{~d}, J=1.1 \mathrm{~Hz}), 126.0(\mathrm{~d}, J=$ $0.9 \mathrm{~Hz}), 127.8$ (q, $\left.\mathrm{CF}_{3}, J=282 \mathrm{~Hz}\right), 129.0,129.4,129.6,132.0$, 132.3, 135.3, 137.5, 137.8, 138.8, 141.3, 141.58, 141.59, 143.5. ${ }^{19} \mathrm{~F}$ NMR $\left(\mathrm{CDCl}_{3}, 376 \mathrm{MHz}\right) \delta, \mathrm{ppm}:-68.72\left(\mathrm{~s}, \mathrm{CF}_{3}\right) . \mathrm{MS}$ (GC-MS, EI), m/z (I $I_{\text {rel. }} \%$ ) - $428[\mathrm{M}]^{+}$(30), 359 (15), 322 (100), 253 (20). HRMS: $\mathrm{C}_{26} \mathrm{H}_{24} \mathrm{~F}_{3} \mathrm{Cl}$ found $428.1517 \mathrm{M}^{+}$; calcd 428.1519.

(1RS,3RS)-3-(4-Chlorophenyl)-1-trifluoromethyl-5, 6-dimethoxy1-(3,4-dimethoxyphenyl)indane (2h). Yield $64 \mathrm{mg}, 73 \%$. Colorless solid, mp 111-114 ${ }^{\circ} \mathrm{C}(\mathrm{MeOH}) .{ }^{1} \mathrm{H} \mathrm{NMR}\left(\mathrm{CDCl}_{3}, 400 \mathrm{MHz}\right)$ $\delta$, ppm: $2.65(\mathrm{dd}, 1 \mathrm{H}, J=12.6 \mathrm{~Hz}, 10.6 \mathrm{~Hz}), 2.91(\mathrm{dd}, 1 \mathrm{H}, J=$ $12.6 \mathrm{~Hz}, 6.9 \mathrm{~Hz}), 3.77$ (s, 3H, $\left.\mathrm{OCH}_{3}\right), 3.80\left(\mathrm{~s}, 3 \mathrm{H}, \mathrm{OCH}_{3}\right), 3.86$ $\left(\mathrm{s}, 3 \mathrm{H}, \mathrm{OCH}_{3}\right), 3.94\left(\mathrm{~s}, 3 \mathrm{H}, \mathrm{OCH}_{3}\right), 4.05(\mathrm{dd}, 1 \mathrm{H}, J=10.6 \mathrm{~Hz}, 6.8$ $\mathrm{Hz}), 6.38$ (s, 1H, H), $6.73(\mathrm{dd}, 1 \mathrm{H}, J=8.5 \mathrm{~Hz}, 1.8 \mathrm{~Hz}), 6.88$ (d, $1 \mathrm{H}, J=8.5 \mathrm{~Hz}$ ), 6.89 (d, 1H, $J=1.8 \mathrm{~Hz}), 7.05$ (s, 1H), 7.14 (d, $2 \mathrm{H}, J=8.4 \mathrm{~Hz}), 7.31(\mathrm{~d}, 2 \mathrm{H}, J=8.4 \mathrm{~Hz}) \cdot{ }^{13} \mathrm{C} \mathrm{NMR}\left(\mathrm{CDCl}_{3}\right.$, $100 \mathrm{MHz}) \delta$, ppm: $47.7(\mathrm{CH}), 48.0\left(\mathrm{CH}_{2}\right), 55.97$ (OMe), 55.99 (OMe), 56.12 (OMe), 56.40 (OMe), 60.4 (q, $\underline{\mathrm{C}}-\mathrm{CF}_{3}, J=26.3 \mathrm{~Hz}$ ), $107.8,108.3$ (d, $J=0.8 \mathrm{~Hz}), 110.7,111.8,121.1,127.7$ (q, $\mathrm{CF}_{3}$, $J=282 \mathrm{~Hz}), 129.4,129.9,130.5,132.5,132.9,139.2,141.8$, $148.8(\mathrm{q}, J=4.1 \mathrm{~Hz}), 150.3 .{ }^{19} \mathrm{~F} \mathrm{NMR}\left(\mathrm{CDCl}_{3}, 376 \mathrm{MHz}\right) \delta$, ppm: $-69.25\left(\mathrm{~s}, \mathrm{CF}_{3}\right)$. MS (GC-MS, EI), $m / z\left(I_{\text {rel. }}, \%\right)-492[\mathrm{M}]^{+}(50)$, 423 (40), 354 (100). HRMS: $\mathrm{C}_{26} \mathrm{H}_{24} \mathrm{~F}_{3} \mathrm{O}_{4} \mathrm{Cl}$ found $492.1318 \mathrm{M}^{+}$; calcd 492.1315 .

(1RS,3RS)-1-Trifluoromethyl-5-methoxy-1,3-diphenylindane (2i). Yield $11 \mathrm{mg}, 76 \%$. Colorless solid, mp 102-104 ${ }^{\circ} \mathrm{C}(\mathrm{MeOH}) .{ }^{1} \mathrm{H}$ NMR ( $\left.\mathrm{CDCl}_{3}, 400 \mathrm{MHz}\right) \delta$, ppm: $2.79(\mathrm{t}, 1 \mathrm{H}, J=12.5 \mathrm{~Hz}), 3.01$ (dd, $1 \mathrm{H}, J=12.5 \mathrm{~Hz}, 11 \mathrm{~Hz}), 3.74(3 \mathrm{H}, \mathrm{OMe}), 4.03(\mathrm{dd}, 1 \mathrm{H}, J=$ $11 \mathrm{~Hz}, 12.5 \mathrm{~Hz}), 6.45(\mathrm{~d}, 1 \mathrm{H}, J=2.4 \mathrm{~Hz}), 6.93(\mathrm{dd}, 1 \mathrm{H}, J=$ $8.4 \mathrm{~Hz}, 2.4 \mathrm{~Hz}), 7.19-7.23(\mathrm{~m}, 2 \mathrm{H}), 7.28$ (d, 1H, $J=7.1 \mathrm{~Hz})$, $7.30-7.36(\mathrm{~m}, 7 \mathrm{H}), 7.51(\mathrm{~d}, 1 \mathrm{H}, J=8.4 \mathrm{~Hz}) .{ }^{13} \mathrm{C} \mathrm{NMR}\left(\mathrm{CDCl}_{3}\right.$, $100 \mathrm{MHz}) \delta$, ppm: $47.3\left(\mathrm{CH}_{2}\right), 48.4(\mathrm{CH}), 55.6(\mathrm{OMe}), 60.2(\mathrm{q}$, $\left.\underline{\mathrm{C}}-\mathrm{CF}_{3}, J=29.5 \mathrm{~Hz}\right), 110.6,113.5,126.6\left(\mathrm{q}, \underline{\mathrm{C}}_{-} \mathrm{CCCF}_{3}, J=1 \mathrm{~Hz}\right)$, 127.2, 127.7 (q, $\left.\mathrm{CF}_{3}, J=282 \mathrm{~Hz}\right), 128.0,128.4,128.6(\mathrm{~d}, J=$ $0.8 \mathrm{~Hz}), 128.7,128.9,132.8,138.0,142.7,149.2,160.6 .{ }^{19} \mathrm{~F}$ NMR $\left(\mathrm{CDCl}_{3}, 376 \mathrm{MHz}\right) \delta$, ppm: -69.46 (s, $\left.\mathrm{CF}_{3}\right)$. MS (GC-MS, 
EI), $m / z\left(I_{\text {rel. }}\right.$ \%) - $368 \mathrm{M}^{+}$(80), 299 (100), 290 (25), 221 (30). HRMS: $\mathrm{C}_{23} \mathrm{H}_{19} \mathrm{~F}_{3} \mathrm{O}$ found $368.1385 \mathrm{M}^{+}$; calcd 368.1388.

1,1,1-Trifluoro-4-(4-methylphenyl)-4-(thiophen-2-yl)butan-2-one (3a). Yield $44 \mathrm{mg}, 77 \%$. Yellow oil. ${ }^{1} \mathrm{H} \mathrm{NMR}\left(\mathrm{CDCl}_{3}, 400 \mathrm{MHz}\right)$ $\delta$, ppm: 2.32 (s, 3H, OMe), 3.40-3.52 (m, 2H, AB-system, $\mathrm{CH}_{2}$ ), 4.86 (t, 1H, CH, $J=7.3 \mathrm{~Hz}$ ), 6.83 (d, 1H, $J=3.5 \mathrm{~Hz}$ ), 6.91 (dd, $1 \mathrm{H}, J=5 \mathrm{~Hz}, 3.5 \mathrm{~Hz}), 7.10-7.19(\mathrm{~m}, 5 \mathrm{H}) .{ }^{13} \mathrm{C} \mathrm{NMR}\left(\mathrm{CDCl}_{3}\right.$, $100 \mathrm{MHz}) \delta$, ppm: $21.2\left(\mathrm{CH}_{3}\right), 40.0(\mathrm{CH}), 44.0\left(\mathrm{CH}_{2}\right), 115.5$ $\left(\mathrm{CF}_{3}, J=292 \mathrm{~Hz}\right), 124.40,124.27,126.9,127.4,129.7,137.2$, 139.3, 146.9, 189.0 (q, $\left.\mathrm{COCF}_{3}, J=35.7 \mathrm{~Hz}\right) .{ }^{19} \mathrm{~F} \mathrm{NMR}\left(\mathrm{CDCl}_{3}\right.$, $376 \mathrm{MHz}) \delta$, ppm: $-79.39\left(\mathrm{~s}, \mathrm{CF}_{3}\right)$. MS (GC-MS, EI), $m / z\left(I_{\text {rel., }}\right.$ $\%)-298 \mathrm{M}^{+}(20), 283\left[\mathrm{M}-\mathrm{CH}_{3}\right]^{+}(15), 229\left[\mathrm{M}-\mathrm{CF}_{3}\right]^{+}(7), 187$ $\left[\mathrm{M}-\mathrm{CH}_{2} \mathrm{COCF}_{3}\right]^{+}$(100). HRMS: $\mathrm{C}_{14} \mathrm{H}_{13} \mathrm{~F}_{3} \mathrm{OS}$ found 286.0640 $\mathrm{M}^{+}$; calcd 286.0640.

1,1,1-Trifluoro-4-(3-methoxyphenyl)-4-phenylbutan-2-one (3b). Yield $44 \mathrm{mg}, 68 \%$. Colorless oil. ${ }^{1} \mathrm{H}$ NMR $\left(\mathrm{CDCl}_{3}, 400 \mathrm{MHz}\right) \delta$, ppm: 3.48 (d, 2H, $\left.\mathrm{CH}_{2}, J=7.5 \mathrm{~Hz}\right), 3.77$ (s, 3H, OMe), $4.63(\mathrm{t}$, $1 \mathrm{H}, \mathrm{CH}, J=7.5 \mathrm{~Hz}), 6.73-6.77(\mathrm{~m}, 2 \mathrm{H}), 6.82(\mathrm{~d}, 1 \mathrm{H}, J=7.8 \mathrm{~Hz})$, 7.20-7.25 (m, 4H), 7.28-7.34 (m, 2H). ${ }^{13} \mathrm{C}$ NMR $\left(\mathrm{CDCl}_{3}\right.$, $100 \mathrm{MHz}) \delta$, ppm: $42.6\left(\mathrm{CH}_{2}\right), 44.7,55.3,109.8,112.0,115.6$ $\left(\mathrm{CF}_{3}, J=292 \mathrm{~Hz}\right), 117.5,127.1,127.6,129.0,130.0,142.4$, 144.2, 160.0, 189.4 (q, $\left.\underline{\mathrm{COCF}}_{3}, J=35.5 \mathrm{~Hz}\right) .{ }^{19} \mathrm{~F} \mathrm{NMR}\left(\mathrm{CDCl}_{3}\right.$, $376 \mathrm{MHz}) \delta$, ppm: $-79.38\left(\mathrm{~s}, \mathrm{CF}_{3}\right)$. MS (GC-MS, EI), $m / z\left(I_{\text {rel., }}\right.$, \%) - $308 \mathrm{M}^{+}$(100), 239 (23), 197 (95). HRMS: $\mathrm{C}_{17} \mathrm{H}_{15} \mathrm{~F}_{3} \mathrm{O}_{2}$ found 308.1021 $\mathrm{M}^{+}$; calcd 308.1024.

\section{Acknowledgements}

This work was supported by Saint Petersburg State University (grant no. 12.50.1558.2013, and 12.38.195.2014) and Russian Scientific Fund (project grant 14-13-00083 for V. M., and V. N.). Spectral studies were performed at the Center for Magnetic Resonance, the Center for Chemical Analysis and Materials Research, and the Research Center for X-ray Diffraction Studies of Saint Petersburg State University. Investigation of the biological activity of indanes $\mathbf{2 a - h}, \mathbf{l}$, was supported by the Russian Scientific Fund (project grant 14-50-00069).

\section{Notes and references}

1 (a) S. G. K. Prakash, M. Mandal, S. Schweizer, N. A. Petasis and G. A. Olah, Org. Lett., 2000, 2, 3173-3176; (b) V. G. Nenajdenko, I. G. Gridnev and E. S. Balenkova, Tetrahedron, 1994, 50, 11023-11038; (c) I. Ashworth, P. Hopes, D. Levin, I. Patel and R. Salloo, Tetrahedron Lett., 2002, 43, 4931-4933; (d) R. J. Andrew and J. M. Mellor, Tetrahedron, 2000, 56, 7261-7266; (e) L. S. Liebeskind and J. Srogl, J. Am. Chem. Soc., 2000, 122, 11260-11261; (f) V. G. Nenajdenko, A. L. Krasovskiy and E. S. Balenkova, Tetrahedron, 2007, 63, 12481-12539; (g) V. G. Nenajdenko, I. F. Leshcheva and E. S. Balenkova, Tetrahedron, 1994, 50, 775-782; (h) V. G. Nenajdenko, A. L. Krasovskiy, M. V. Lebedev and E. S. Balenkova, Synlett, 1997, 1349-
1350; (i) V. G. Nenajdenko, A. V. Sanin and E. S. Balenkova, Russ. Chem. Rev., 1999, 68, 437-458.

2 (a) R. P. Singh, R. L. Kirchmeier and J. M. Shreeve, Org. Lett., 1999, 1, 1047-1049; (b) D. Zhang and C. Yuan, Tetrahedron, 2008, 64, 2480-2488; (c) M. R. Bryce, M. A. Chalton, A. Chesney, D. Catterick, J. W. Yao and J. A. K. Howard, Tetrahedron, 1998, 54, 3919-3928; (d) J.-N. Volle and M. Schlosser, Eur. J. Org. Chem., 2002, 1490-1492; (e) A. Yu. Rulev, V. M. Muzalevskiy, E. V. Kondrashov, I. A. Ushakov, A. R. Romanov and V. G. Nenajdenko, Org. Lett., 2013, 15, 2726-2729.

3 (a) Z. Pei, Y. Zheng, J. Nie and J.-A. Ma, Tetrahedron Lett., 2010, 51, 4658-4661; (b) S. Sasaki, T. Yamauchi and K. Higashiyama, Tetrahedron Lett., 2010, 51, 2326-2328; (c) Y. Xin, J. Zhao, J. Han and S. Zhu, J. Fluorine Chem., 2010, 131, 642-645; (d) M. A. P. Martins, A. F. C. Flores, G. P. Bastos, N. Zanatta and H. G. Bonacorso, J. Hetercycl. Chem., 1999, 36, 837-840; (e) N. Zanata, D. M. Borchhardt, S. H. Alves, H. S. Coelho, A. M. C. Squzani, T. M. Marchi, H. G. Bonacorso and M. A. P. Martins, Bioorg. Med. Chem. Lett., 2006, 14, 3174-3184.

4 (a) V. J. Majo, J. Prabharkaran, N. R. Simpson, R. L. Van Heertum, J. J. Mann and J. S. D. Kumar, Bioorg. Med. Chem. Lett., 2005, 15, 4268-4271; (b) M. A. P. Martins, R. F. Blanco, C. M. P. Pereira, P. Beck, S. Brondani, W. Cunico, N. E. K. Zimmermann, H. G. Bonacorso and N. Zanatta, J. Fluorine Chem., 2002, 118, 69-72; (c) A. F. C. Flores, S. Brondani, L. Puzziti, M. A. P. Martins, N. Zanatta, H. G. Bonacorso and D. C. Flores, Synthesis, 2005, 2744-2750; (d) M. A. P. Martins, G. M. Siquera, G. P. Bastos, H. G. Bonacorso and N. Zanatta, J. Heterocycl. Chem., 1996, 33, 1619-1622; (e) P. Yeh, D. S. B. Daniels, D. B. Cordes, A. M. Z. Slawin and A. D. Smith, Org. Lett., 2014, 16, 964-967; (f) K. Funabiki, A. Isomura, Y. Yamaguchi, W. Hashimoto, K. Matsunaga, K. Shibata and M. Matsui, J. Chem. Soc., Perkin Trans. 1, 2001, 25782582; $(g)$ K. Funabiki, H. Nakamura, M. Masaki and K. Shibata, Synlett, 1999, 756-758; (h) H. G. Bonacorso, A. P. Wentz, N. Zanatta and M. A. P. Martins, Synthesis, 2001, 1505-1508; (i) N. Zanatta, D. C. Flores, C. C. Madruga, A. F. C. Flores, H. G. Bonacorso and M. A. P. Martins, Synthesis, 2003, 894-898; (j) H. G. Bonacorso, H. Lewandowski, R. L. Drekener, M. B. Costa, C. M. P. Pereira, A. D. Wastowski, C. Peppe, M. A. P. Martins and N. Zanatta, J. Fluorine Chem., 2003, 122, 159-163; (k) H. G. Bonacorso, I. S. Lopes, A. D. Wastowski, M. A. P. Martins and N. Zanatta, J. Fluorine Chem., 2003, 120, 29-32.

5 (a) T. Hiyama, Organofluorine Compounds. Chemistry and Applications, Springer, Berlin, 2000; (b) R. D. Chambers, Fluorine in Organic Chemistry, Blackwell, Oxford, 2004; (c) P. Kirsch, Modern Fluoroorganic Chemistry: Synthesis, Reactivity, Applications, Wiley-VCH, Weinheim, 2004; (d) K. Uneyama, Organofluorine Chemistry, Blackwell, Oxford, 2006; (e) G. Theodoridis, Fluorine-containing agrochemicals: An overview of recent developments, in Advances 
in Fluorine Science, ed. A. Tressaud, Elsevier, Amsterdam, 2006, vol. 2, pp. 121-175; (f) J. P. Bégué and D. BonnetDelpon, Bioorganic and Medicinal Chemistry of Fluorine, Wiley, Hoboken, 2008; ( $g$ ) Fluorine and Health, Molecular Imaging, Biomedical Materials and Pharmaceuticals, ed. A. Tressaud and G. Haufe, Elsevier, Amsterdam, 2008, pp. 553-778; (h) Fluorinated Heterocycles, ed. A. Gakh and K. L. Kirk, Oxford University Press, Oxford, 2008; (i) Fluorinated Heterocyclic Compounds: Synthesis, Chemistry, and Applications, ed. V. A. Petrov, Wiley, Hoboken, 2009; (j) Fluorine in Heterocyclic Chemistry, ed. V. G. Nenajdenko, Springer, Berlin, Heidelberg, 2014.

6 (a) H. M. H. Alkhafaji, D. S. Ryabukhin, V. M. Muzalevskiy, A. V. Vasilyev, G. K. Fukin, A. V. Shastin and V. G. Nenajdenko, Eur. J. Org. Chem., 2013, 1132-1143; (b) H. M. H. Alkhafaji, D. S. Ryabukhin, V. M. Muzalevskiy, L. V. Osetrova, A. V. Vasilyev and V. G. Nenajdenko, Russ. J. Org. Chem., 2013, 49, 327-341.

7 A. N. Kazakova, R. O. Iakovenko, V. M. Muzalevskiy, I. A. Boyarskaya, M. S. Avdontceva, G. L. Starova, A. V. Vasilyev and V. G. Nenajdenko, Tetrahedron Lett., 2014, 55, 6851-6855.

8 R. O. Iakovenko, V. M. Muzalevskiy, V. G. Nenajdenko and A. V. Vasilyev, Russ. J. Org. Chem., 2015, 51, 436-438.

9 (a) G. A. Olah, G. K. S. Prakash, A. Molnar and J. Sommer, Superacid Chemistry, Wiley, New York, 2009; (b) G. A. Olah and D. A. Klumpp, Superelectrophiles and Their Chemistry, Wiley, New York, 2008; (c) A. V. Vasilyev, Russ. Chem. Rev., 2013, 82, 187-203.

10 (a) R. G. Parr, L. V. Szentpaly and S. Liu, J. Am. Chem. Soc., 1999, 121, 1922-1924; (b) P. K. Chattaraj, S. Giri and S. Duley, Chem. Rev., 2011, 111, PR43-PR75.

11 V. G. Nenajdenko, N. E. Shevchenko, E. S. Balenkova and I. V. Alabugin, Chem. Rev., 2003, 103, 229-282.

12 (a) T. Ohwada, N. Yamagata and K. Shudo, J. Am. Chem. Soc., 1991, 113, 1364-1373; (b) T. Suzuki, T. Ohwada and K. Shudo, J. Am. Chem. Soc., 1997, 119, 6774-6780; (c) K. Yu. Koltunov, S. Walspurger and J. Sommer, Tetrahedron Lett., 2005, 46, 8391-8394; (d) J. Guillon, P. Dallemange, J.-M. Leger, J. Sopkova, P. R. Bovy, C. Jarry and S. Rault, Bioorg. Med. Chem., 2002, 10, 1043-1050; (e) G. K. S. Prakash, P. Yan, B. Torok and G. A. Olah, Catal. Lett., 2003, 87, 109-112; ( $f$ ) R. Rendy, Y. Zhang, A. Gomez and D. A. Klumpp, J. Org. Chem., 2004, 69, 2340-2347; (g) S. Chassaing, M. Kumarraja, P. Pale and J. Sommer, Org. Lett., 2007, 9, 3889-3892; (h) A. G. Posternak, R. Yu. Garlyuskayte and L. M. Yagupolskii, J. Fluorine Chem., 2010, 131, 274-277; (i) G. K. S. Prakash, F. Paknia, A. Narayanan, G. Rasul, T. Mathew and G. A. Olah, J. Fluorine Chem., 2012, 143, 292-302; $(j)$ B. V. Ramulu, A. G. K. Reddy and G. Satyanarayana, Synlett, 2013, 868872; (k) W. Yin, Y. Ma, J. Xu and Y. Zhao, J. Org. Chem., 2006, 71, 4312-4315; (l) Y. Zhou, X. Li, S. Hou and J. Xu, J. Mol. Catal. A: Chem., 2012, 365, 203-211; (m) K. Yu. Koltunov, S. Walspurger and J. Sommer, Chem. Commun., 2004, 1754-1755; (n) D. A. Klumpp, R. Rendy,
Y. Zhang, A. Gomez and A. McElrea, Org. Lett., 2004, 6, 1789-1792; (o) K. Yu. Koltunov, S. Walspurger and J. Sommer, Tetrahedron Lett., 2004, 45, 3547-3549; ( $p$ ) D. N. Zakusilo, D. S. Ryabukhin, I. A. Boyarskaya, O. S. Yuzikhin and A. V. Vasilyev, Tetrahedron, 2015, 71, 102-108; (q) K. Yu. Koltunov, S. Walspurger and J. Sommer, Eur. J. Org. Chem., 2004, 4039-4047; (r) K. Yu. Koltunov, M. M. Shakirov, I. B. Repinskaya and V. A. Koptug, Zh. Org. Khim., 1991, 27, 2622-2623; $(s)$ K. Yu. Koltunov, M. M. Shakirov, I. B. Repinskaya and V. A. Koptug, Zh. Org. Khim., 1991, 27, 2622-2623; $(t)$ K. Yu. Koltunov and I. B. Repinskaya, Zh. Org. Khim., 1994, 30, 90-93; (u) A. V. Vasilyev, S. Walspurger, M. Haouas, J. Sommer, P. Pale and A. P. Rudenko, Org. Biomol. Chem., 2004, 2, 3483-3489.

13 (a) C. Aubert, J.-P. Bégué, D. Bonnet-Delpon and D. Mesureur, J. Chem. Soc., Perkin Trans. 1, 1989, 395-399; (b) A. Abouabdellah, C. Aubert, J.-P. Begue, D. BonnetDelpon and J. Guilhem, J. Chem. Soc., Perkin Trans. 1, 1991, 1397-1403; (c) K. Dong, Y. Li, Z. Wang and K. Ding, Angew. Chem., Int. Ed., 2013, 52, 14191-14195; (d) R. J. Lorentzen, J. H. Brewster and H. E. Smith, J. Am. Chem. Soc., 1992, 114, 2181-2187; (e) K. Kundu, J. V. McCullagh and A. T. Morehead Jr., J. Am. Chem. Soc., 2005, 127, 1604216043; (f) M. J. O’Connor, K. N. Boblak, M. J. Topinka, P. J. Kindelin, J. M. Briski, C. Zheng and D. A. Klumpp, J. Am. Chem. Soc., 2010, 132, 3266-3267; (g) P. G. Gassman, J. A. Ray, P. G. Wenthold and J. W. Mickelson, J. Org. Chem., 1991, 56, 5143-5146; (h) T. Furukawa, T. Nishimine, E. Tokunaga, K. Hasegawa, M. Shiro and N. Shibata, Org. Lett., 2011, 13, 3972-3975.

14 E. L. Eliel, S. H. Wilen and L. N. Mander, Stereochemistry of Organic Compounds, Wiley, New York, 1994.

15 G. I. McGrew, J. Temaismithi, P. J. Carroll and P. J. Walsh, Angew. Chem., Int. Ed., 2010, 49, 5541-5554.

16 (a) M. G. Gorbunova, I. I. Gerus and V. P. Kukhar, J. Fluorine Chem., 1993, 65, 25-28; (b) N. Matsumoto and M. Takahashi, Tetrahedron Lett., 2005, 46, 5551-5554; (c) S. V. Pazenok, I. I. Geus, E. A. Chaika and L. M. Yagupol'skiy, Zh. Org. Khim., 1989, 25, 379-381.

17 A. C. Howlett, Prostaglandins Other Lipid Mediators, 2002, 68-69, 619-631.

18 R. G. Pertwee, Int. J. Obes., 2006, 30, S13-S18.

19 R. G. Pertwee, Expert Opin. Invest. Drugs, 2000, 9, 15531571.

20 C. C. Felder, K. E. Joyce, E. M. Briley, M. Glass, K. P. Mackie, K. J. Fahey, G. J. Cullinan, D. C. Hunden, D. W. Johnson, M. O. Chaney, G. A. Koppel and M. Brownstein, J. Pharmacol. Exp. Ther., 1998, 284, 291297.

21 B. Dean, S. Sundram, R. Bradbury, E. Scarr and D. Copolov, Neurosci., 2001, 103, 9-15.

22 V. Vichai and K. Kirtikara, Nat. Protoc., 2006, 1, 11121116.

23 B. Bosier, G. G. Mucciouli, E. Hermans and D. M. Lambert, Biochem. Pharmacol., 2010, 80, 1-12. 
24 M. Pazos, E. Núñez, C. Benito, R. Tolón and J. Romero, Pharmacol., Biochem. Behav., 2005, 81, 239-247.

25 Y. Cheng and S. A. Hitchcock, Expert Opin. Invest. Drugs, 2007, 16, 951-965.

26 C. Benito, E. Núñez, R. M. Tolón, E. J. Carrier, A. Rábano, C. J. Hillard and J. Romero, J. Neurosci., 2003, 23, 1113611141.

27 SHELXS, G. M. Sheldrick, Acta Crystallogr., Sect. A: Fundam. Crystallogr., 2008, 64, 112-122.

28 O. V. Dolomanov, L. J. Bourhis, R. J. Gildea, J. A. K. Howard and H. Puschmann, J. Appl. Crystallogr., 2009, 42, 339-341.

29 M. J. Frisch, G. W. Trucks, H. B. Schlegel, G. E. Scuseria, M. A. Robb, J. R. Cheeseman, J. A. Montgomery Jr., T. Vreven, K. N. Kudin, J. C. Burant, J. M. Millam, S. S. Iyengar, J. Tomasi, V. Barone, B. Mennucci, M. Cossi, G. Scalmani, N. Rega, G. A. Petersson, H. Nakatsuji,
M. Hada, M. Ehara, K. Toyota, R. Fukuda, J. Hasegawa, M. Ishida, T. Nakajima, Y. Honda, O. Kitao, H. Nakai, M. Klene, X. Li, J. E. Knox, H. P. Hratchian, J. B. Cross, C. Adamo, J. Jaramillo, R. Gomperts, R. E. Stratmann, O. Yazyev, A. J. Austin, R. Cammi, C. Pomelli, J. W. Ochterski, P. Y. Ayala, K. Morokuma, G. A. Voth, P. Salvador, J. J. Dannenberg, V. G. Zakrzewski, S. Dapprich, A. D. Daniels, M. C. Strain, O. Farkas, D. K. Malick, D. Rabuck, K. Raghavachari, J. B. Foresman, J. V. Ortiz, Q. Cui, A. G. Baboul, S. Clifford, J. Cioslowski, B. B. Stefanov, G. Liu, A. Liashenko, P. Piskorz, I. Komaromi, R. L. Martin, D. J. Fox, T. Keith, M. A. Al-Laham, C. Y. Peng, A. Nanayakkara, M. Challacombe, P. M. W. Gill, B. Johnson, W. Chen, M. W. Wong, C. Gonzalez and J. A. Pople, GAUSSIAN 03, Revision B.01, Gaussian, Inc., Pittsburgh, PA, 2003. 